NBER WORKING PAPER SERIES

\title{
THE MARKET VALUE OF R\&D IN WEAK INNOVATION REGIMES: EVIDENCE FROM INDIA
}

\author{
Sunil Kanwar \\ Bronwyn H. Hall \\ Working Paper 21196 \\ http://www.nber.org/papers/w21196 \\ NATIONAL BUREAU OF ECONOMIC RESEARCH \\ 1050 Massachusetts Avenue \\ Cambridge, MA 02138 \\ May 2015, Revised January 2018
}

We are grateful to several anonymous referees for extremely useful comments. The views expressed herein are those of the authors and do not necessarily reflect the views of the National Bureau of Economic Research.

NBER working papers are circulated for discussion and comment purposes. They have not been peer-reviewed or been subject to the review by the NBER Board of Directors that accompanies official NBER publications.

(C) 2015 by Sunil Kanwar and Bronwyn H. Hall. All rights reserved. Short sections of text, not to exceed two paragraphs, may be quoted without explicit permission provided that full credit, including (C) notice, is given to the source. 
The Market Value of R\&D in Weak Innovation Regimes: Evidence from India

Sunil Kanwar and Bronwyn H. Hall

NBER Working Paper No. 21196

May 2015, Revised January 2018

JEL No. G12,O16,O30

\begin{abstract}
$\underline{\text { ABSTRACT }}$
We revisit the relationship between market value and innovation in the context of manufacturing firms in a developing country, using data for Indian firms from 2001 through 2010. Surprisingly, we find that financial markets value the R\&D investment of Indian firms the same or higher than it values such investment in developed economies such as the US and European countries, suggesting some degree of underinvestment. The paper explores the use of a proxy for the option value of $R \& D$ and finds that this can account for a very small part of the $R \& D$ valuation (about 10 per cent). We also find that the market value $R \& D$ relationship does not vary significantly across industry groups, although these results are rather imprecise.
\end{abstract}

\author{
Sunil Kanwar \\ Delhi School of Economics \\ University of Delhi \\ Delhi 110007 \\ India \\ sunil_kanwar@econdse.org \\ Bronwyn H. Hall \\ University of California at Berkeley \\ 123 Tamalpais Road \\ Berkeley, CA 94708 \\ and NBER \\ bhhall@nber.org
}




\section{Introduction}

Innovation is often considered to be the prime motive force behind economic growth. Firms spend large amounts of scare resources on innovative activities, and it is therefore desirable to know whether financial markets value innovating firms differently from non-innovating ones. Of course, innovative activity tends to be highly risky by its very nature, and may take time to yield returns. Hence the interest in examining market value, which should reflect the present discounted value of the expected profits that all such investments are likely to generate (Griliches 1981; Hayashi 1982). While there is persuasive empirical evidence that stock markets in advanced economies do value innovative activity by firms, can we expect the same in the context of less developed economies? A major reason for doubt is the fact that the predominant share of intellectual capital appears to be generated in a handful of developed economies, whether measured in terms of the inputs into innovation (such as research and development expenditure $^{4}$ ) or in terms of the outputs of innovation (such as patents, WIPO 2014).

Nevertheless, the literature does recognize the existence of innovative activity in a few developing countries, even though this may manifest itself primarily in the form of process patents, or utility models, or even smaller innovations (Bogliacino et al. 2012). Although these innovations may be small in the larger scheme of things, they appear to have value insofar as they contribute to increasing firm productivity and profitability. Moreover, innovation may be directed towards imitation and diffusion in some cases, which may be just as important in generating profits and hence market value. In view of these arguments, questions about the stock market's responsiveness become as relevant in the developing country context as they have historically been in the context of developed economies. Thus, are more innovative firms valued more highly than less innovative ones, ceteris paribus? Is the market valuation responsive to the success or qualitative aspects of innovation spending? Does the relationship between firm market value and innovative activity vary across industries, and if so, how? Is the variation in the market value-innovation relationship across industries, if any, related to variations in economic performance across these industries? In this study we explore these questions in the context of manufacturing industries in the emerging economy of India.

The prior literature on the market valuation of the intangible assets of the firm has been informative on a number of counts. Griliches (1981), using US data, reports that a dollar

\footnotetext{
${ }^{4}$ See Wikipedia, which suggests that just 5 countries (US, Japan, Germany, France, UK and South Korea) accounted for about 55 per cent of R\&D worldwide in 2010:

http://en.wikipedia.org/wiki/List of countries_by research_and_development_spending
} 
increase in R\&D raises market value of the firm by about $\$ 2$ in the long run. Bloom and Van Reenen (2002) confirm these findings with UK data, finding that patents have a significant (immediate) impact on firm market value, such that doubling the citation-weighted patent stock raises firm value (per unit of physical capital) by about 43\%. Hall (1993a) highlights the fact that the relationship is not stable over time, while Hall, Jaffe and Trajtenberg (2005) report a smaller increase of about $25 \%$ with a doubling of the (normalized) stock of knowledge capital.

Further studies show that the stock market valuation differs considerably across UK industries (Greenhalgh and Rogers 2006), that during some periods the market may well value intangible assets more than a firm's tangible assets (Hall 1993), and that the average value of patents fell whereas that of trademarks rose for a sample of Australian firms during the 1989-2002 period (Griffiths and Webster 2006). An exception to these studies appears to be that of Hall and Oriani (2006) who report only a weak relationship for the market valuation of intangible assets in Italy. Hall (2005) emphasizes the fact that the relationship between market value and R\&D (or other proxies for innovation) is that of a hedonic equilibrium rather than a causal relationship, and that interpretation of the valuation coefficient depends heavily on the assumed depreciation rate for $\mathrm{R} \& \mathrm{D}$ assets. ${ }^{5}$

It is striking, however, that the predominant bulk of the empirical evidence relates to the US, with a small fraction for some European economies such as the UK and Italy (see Czarnitzki et al. 2006 for a recent survey). Do similar results apply to less developed countries where firms are engaged in some innovative activity and the stock market is reasonably well functioning? In view of the recent trend for multinationals to locate some of their innovative activity in certain developing countries, these are questions that might be of interest to developed country entities as well.

This study contributes to this literature by adding evidence for firms in the emerging economy of India, for which there has only been one prior such study (Chadha and Oriani 2010). We use data for a more recent time period than theirs, during which GDP growth averaged $7.5 \%$ per annum and the economy displayed numerous signs of higher productivity (Topalova and Khandelwal 2005; and the references therein), and innovativeness (The Economist 2010). This performance inevitably leads to the question whether the higher productivity and innovativeness have been reflected in the domestic stock market movements during this period. We also have data for both the Bombay and National Stock Exchanges, rather than data from the Bombay exchange only, as in the earlier study. In addition, we employ a nonlinear model, rather than a linear model based on suppositions unsupported by the data. We explore the use of a

${ }^{5}$ See also Rosen (1974) and Ekeland et al. (2004) for the theory of price determination in hedonic models. 
measure based on unexpected profitability as a proxy for the efficacy of the R\&D stock, to augment specifications used in the received literature. Furthermore, we also include a measure of risk to explore the option value of R\&D.

Our data cover a sample of 380 Indian firms in the manufacturing sector during the period 2001-2010. We find that both R\&D and advertising capital are valued in these firms, with the marginal value of R\&D slightly higher than its share, and the marginal value of advertising slightly lower. In the context of a relatively weak innovation milieu, where most firms have only 'small' or incremental innovations, this finding suggests that R\&D investments are nevertheless as productive as in developed economies. The financial market values the R\&D investment of Indian firms (with a knowledge capital coefficient of 1.76) higher than the markets in developed economies such as the US, France, and Germany (with knowledge capital coefficients of 0.80 , 0.41 and 0.36 respectively, according to a comparable study), suggesting considerable underinvestment in knowledge capital by Indian firms. We also explore a proxy for the option value of $R \& D$ and find a positive impact of market uncertainty on market value in agreement with the theoretical literature, though this accounts for only a small part of the R\&D valuation (about 10 per cent). Finally, we find relatively little variation across industrial sectors in these relationships; although the supplier-dominated sector, a low-tech manufacturing sector, appears to differ from the others, it is a very small sector and the differences from the other sectors are largely insignificant.

The detailed analysis is presented in the following sections. In the next section we give a brief overview of the recent developments in the Indian economy, paying special attention to innovative indicators and the stock market. Section 3 develops the relationship to be estimated. Section 4 details the data set and explains the computation of the model variables. Section 5 discusses the detailed empirical results, as well as their economic significance. Section 6 examines the heterogeneity of the relationship across industry groups. Section 7 studies whether this variation across industries is explained by variations in expected firm/industry performance. Finally, section 8 briefly presents the conclusions.

\section{The Indian context}

Altenburg et al. (2007) argue that India has now become a major producer of products and services for global markets, which is part of an overall shift in the distribution of industrial activity away from OECD countries. They show that human capital, India's most important input into its innovation capability, has risen very substantially between 1995 and 2004, in several dimensions - total graduates, engineering graduates, science graduates, etc. The number of patents granted by the US Patent and Trademark Office to Indian applicants rose substantially 
between 1995 and 2005, albeit from a small base, both in absolute terms as well as a proportion of the total foreign patents. The UNCTAD Innovation Capability Index ranks India at 26 out of 125 nations. Thus, data based on innovation systems, global value chains and global professional networks provide evidence of mounting innovation effort, which if sustained, is likely to raise innovation capability rapidly, even though initially in non-strategic areas.

Saxenian (2002), focusing on IT, attributes the buildup of innovation capability in India to the 'New Argonauts' or the highly mobile and technically-skilled entrepreneurs, engineers and scientists, who transport their knowledge and capital gained in the US to India. Athreye and Kapur (2009), Chittoor and Ray (2007) and Goldstein (2008) report, that in recent years Indian firms have increasingly internationalized via significant outward investment and overseas mergers and acquisitions. Thus, FDI flows from India grew from near 0 in 1990 to about \$14 billion in 2007, with the FDI stock rising from near 0 to about $\$ 30$ billion over the same period. These investments have spanned various sectors such as steel, pharmaceuticals, IT, and food and beverages, with cross-border acquisitions by Indian firms averaging $\$ 1.5$ billion annually over 2005-07. These represent attempts to acquire strategic assets such as technology and inputs, which would augment innovation capability. Several Indian firms supply sophisticated inputs to international firms, a case in point being auto ancillary units where "global automakers have been giving responsibilities for research, design, development, testing, validation, and integration to vendors" in India (Singh et al. 2007).

Not only are the Indian firms growing in global importance, its stock market has also matured to an extent where it may be expected to discern such changes. Lamm Jr. (2010), in his study of Indian (and some other emerging market) equity returns, comments that "equity markets ... trading today is increasingly driven by fundamentals and more complete information than ever before". This is in consonance with the earlier findings of Mukhopadhyay and Sarkar (2003) for the post-1991 period. Tas et al. (2010) report a strong relationship between national stock market indices in India (and some other emerging economies) and the price-book, priceearnings and dividend-yield ratios, just as in mature economies. Thus, a broad reading of the research in this area gives the impression that although there is further need to improve various aspects of Indian stock markets such as information disclosure norms, monitoring and supervision mechanisms etc., these markets are increasingly driven by economic fundamentals. ${ }^{6}$ Thus one aim of our research is to examine whether the valuation of R\&D and advertising capital in these firms also follows the pattern observed in more developed financial markets.

\footnotetext{
${ }^{6}$ Also see the material referred to in footnote 9 below.
} 


\section{The market value model}

On the premise that the innovative activity of firms leads to the generation of 'knowledge capital', we measure the private value of firm innovation in terms of the marginal effect of a unit change in knowledge capital on the capitalized market value of a firm, following Griliches (1981) and Hall (1993a). If stock markets are efficient and the firm is pursuing an optimal investment strategy, in any given period the market values the assets owned by the firm (physical capital, knowledge capital, and other intangible capital) as the present discounted value of the expected returns to those assets. The notion of physical capital is well-defined (plant, equipment, inventories, etc.) and does not require further elaboration. Knowledge capital refers to the stock of knowhow embodied in the ideas, innovations, and inventions that a firm has title to, where this entitlement may be explicit as in the case of ownership of formal intellectual property rights such as patents, design rights, or copyrights, or else implicit as with trade secrets or other informal knowledge.

In principle, other intangible capital includes a wide range of firm-specific assets such as its customer or distribution networks, the firm-specific human capital of its employees, and the value of its brands and reputation. Unfortunately much of this is unmeasured and in some cases unmeasurable. We focus here on one aspect, reputational capital, including the value of the firm's brands. Reputation can be thought of as a stock that grows and diminishes over time as a result of the firm's activities. However, it is difficult to measure, because it depends on a number of diverse factors. Firm advertising is one important input into a firm's reputation, but aftersales service, product quality, product development expenses and firm-specific training (as in Corrado et al. 2009), etc. also contribute towards its reputation. Often data on most of these inputs are not available, and therefore it is more accurate to refer to it as advertising capital. In this sense, advertising capital is an imperfect proxy for other intangible capital.

In addition to the magnitudes of these capital stocks, the market's valuation of a firm would also depend on the quality or efficiency of the capital stocks created by the various types of investment; just as the market value of any commodity would depend both on its quantity as well as its qualitative aspects. In this paper we refer to the efficiency with which these stocks generate current profits as their "efficacy." Although the efficacy of all three types of capital may differ across firms and over time, one would expect this to be particularly true of the stock of knowledge capital, in part because of the stochastic nature of the innovation process. For instance, some R\&D investment might result in very small innovations, whereas other R\&D investment might generate major breakthroughs. Even though the stock of knowledge capital generated in both these cases may be of similar magnitude, the efficacy of the capital stock would be much higher in the latter case. 
Theory does not necessarily provide an explicit form for the market value equation except under very restrictive assumptions (Wildasin 1984; Hayashi and Inoue 1991). We follow the empirical literature and use a first order approximation that allows for returns to scale. Thus, the market value of a firm ( $V$ ) may be expressed as a function of its stocks of physical capital $\left(K_{P}\right)$, knowledge capital $\left(K_{K}\right)$, and other intangible capital $\left(K_{O I}\right)$, as well as the efficacy of its capital stocks $(E)$, according to the relation

$V=p\left(K_{P}+\beta K_{K}+\gamma K_{O I}+\delta E\right)^{\sigma}$

where $p$ is the market premium of the firm's stock value over its replacement cost of capital, $\beta$ is the shadow price of the knowledge capital, $\gamma$ is the shadow price of other intangible capital, $\delta$ is the shadow price of the quality of capital, and $\sigma$ is the scale factor in this valuation relation. Although one could have considered three different efficacy variables corresponding to the three different stocks of capital, we preferred to be circumspect in our modelling, knowing the data limitations. Taking logarithms and subtracting $\ln K_{P}$ from both sides, this relationship may be rewritten as

$\ln \left(\frac{V}{K_{P}}\right)=\ln (p)+\sigma \ln \left(K_{P}+\beta K_{K}+\gamma K_{O I}+\delta E\right)-\ln K_{P}$

or

$\ln \left(\frac{V}{K_{P}}\right)=\ln (p)+\rho \ln K_{P}+\sigma \ln \left(1+\beta \frac{K_{K}}{K_{P}}+\gamma \frac{K_{O I}}{K_{P}}+\delta \frac{E}{K_{P}}\right)$

where $\rho \equiv \sigma-1$. The market premium $p$ would be one in equilibrium (if all capital measurements are correct and there is some kind of steady state). However, usually it will differ from one because of overall macroeconomic shocks and other things that cause market volatility. It also may differ across firms if there are left-out assets or differences in firm qualities that are not captured by their capital stocks.

Allowing for firm and year effects to capture some of the variability in the market premium, the estimating equation corresponding to the above specification is the following:

$\ln \left(\frac{V}{K_{P}}\right)_{i t}=\rho \ln \left(K_{P}\right)_{i t}+\sigma \ln \left[1+\beta\left(\frac{K_{K}}{K_{P}}\right)_{i t}+\gamma\left(\frac{K_{O I}}{K_{P}}\right)_{i t}+\delta\left(\frac{E}{K_{P}}\right)_{i t}\right]+\alpha_{i}+\mu_{t}+\epsilon_{i t}$

where $\alpha_{i}$ signifies firm-specific 'time constant' factors such as (possibly) management skills or tax rates, $\mu_{t}$ references factors that affect the sample firms similarly but may vary over time such as the 'depth' of stock markets, and $\epsilon_{i t}$ is the stochastic error term. 
Given the twin simplifying claims that $\sigma=1,7$ and that $\ln (1+x) \approx x$ when $x$ is 'small', 8 as in some of the literature reviewed earlier, the model in (4) yields the alternative estimating equation:

$\ln \left(\frac{V}{K_{P}}\right)_{i t} \approx \beta\left(\frac{K_{K}}{K_{P}}\right)_{i t}+\gamma\left(\frac{K_{O I}}{K_{P}}\right)_{i t}+\delta\left(\frac{E}{K_{P}}\right)_{i t}+\alpha_{i}+\mu_{t}+\epsilon_{i t}$

To appreciate the difference between estimating equations (4) and (5), note that the implied (partial) elasticities of firm market value with respect to knowledge capital $\left(\partial \ln V / \partial \ln K_{K}\right)$ are

$\sigma \beta K_{K} /\left(K_{P}+\beta K_{K}+\gamma K_{O I}+\delta E\right)$

and $\beta K_{K} / K_{P}$, respectively. Thus, if in fact $\sigma$ is found to be close to unity, one would expect specification (5) to yield upwardly biased estimates of the change in the capitalized market value of a firm as a result of a change in the stock of its knowledge capital. But if $\sigma$ differs from unity, the elasticity estimate from (5) could be upwardly or downwardly biased. Of course, from the policy perspective total elasticities would serve better than partial elasticities, for they would include not just the direct impact of a change in knowledge capital on market value, but the indirect impacts as well. For instance, an increase in the stock of knowledge capital may lead to a reduction in physical capital insofar as it raises the efficiency of use of physical capital. If this indirect effect dominates the direct effect of the first round increase in knowledge capital, the total impact may be a decline in market value. Alternatively, an increase in the stock of knowledge capital may lead to an increase in the stock of advertising capital, and the total impact would be a larger increase in market value than in the absence of the indirect effect. Incorporating such indirect effects, however, would require a more elaborate model that allows for interactions between the different types of capital stocks, and identification of this more complex model would be difficult in our relatively small dataset.

To render estimating equations (4) and (5) estimable, we need to be able to measure knowledge capital, other intangible capital, and the overall quality of capital. Although researchers have attempted to capture knowledge capital both in terms of research and development investment and in terms of patents and other intellectual property (Hall and MacGarvie 2010, Greenhalgh and Rogers 2006, Hall et al. 2005, Bloom and Van Reenen 2002, Blundell et al. 1999, Cockburn and Griliches 1988), the former has been shown by Hall et al. 2005 to be a better value predictor. This is not surprising, because R\&D is measured in currency units, whereas patents (or trademarks and other measures) are typically counts of items whose underlying value can

\footnotetext{
${ }^{7}$ In estimation we check this assumption by including log $\left(K_{P}\right)$ in the regression. The estimate of this coefficient was always insignificantly different from zero, suggesting that this constraint is appropriate.

8 The approximation $\ln (1+x) \approx x$ is exact when $x=0$ and becomes increasingly poor as $x$ increases in value from zero, while remaining fairly good for $|x| \leq 0.2$. Our data include a number of observations with knowledge or other capital that is much greater than physical capital, leading to values of $x$ that are much larger than unity, so the approximation will not be very good in those cases.
} 
vary enormously (see Griliches et al. 1991 for a thorough discussion of this issue). We describe the exact construction of our knowledge capital variable using R\&D data in Section 3.1 below. Corrado et al. (2009) list the components of other intangible investment as software investment, product level development expense not captured by $R \& D$, and investments in economic competency such as firm-specific training. We do not observe all of these investments, but we do observe advertising expenditure, which is associated with the introduction of new products and the development of brand-related capital. We use this variable to construct a stock of advertising capital, as described in Section 3.2 below. Further, as a first approximation we represent the efficacy of the firm's capital $(E)$ by the post-tax profit of firms appropriately modified, for more efficacious capital (or that associated with 'meaningful' innovations from the production viewpoint) should increase profit more than less efficacious capital (or that associated with no innovations or else innovations that are not practically useful). The method we use to construct an input-adjusted profit measure as a proxy for innovation efficacy is explained in Section 3.3 below.

\section{Data and Variables}

The data we use are based on a large sample of firms drawn from the 'Prowess' database, sold by the Centre for Monitoring Indian Economy (CMIE 2012). They pertain to firms traded on the Bombay and National Stock Exchanges of the country. ${ }^{9}$ Only firms for which data were available for physical capital and R\&D for the full ten-year period 2001-2010 were retained. This left us with data on 380 firms for the period 2001-2010, or 3800 observations. ${ }^{10}$ To minimize the influence of outliers, observations with a market value to physical capital ratio exceeding 20 or a debt to assets ratio exceeding 5 were dropped,11 which left us with a sample of 3551 observations relating to 380 firms, with an average of 9.4 years of data for each firm. Some of these observations clearly indicated a break in the firm data (reorganization, bankruptcy, possible major errors in reporting, etc.); when this occurred we defined a new firm going forward, to avoid measurement error bias in the dynamic models. We also required at least three years of data per firm, to ensure identification of the dynamic models, which removed a few more observations. After this data cleaning, we are left with a sample of 3,494 observations

\footnotetext{
${ }^{9} \mathrm{~A}$ brief description of the Indian stock exchanges can be found at Investopedia: http://www.investopedia.com/articles/stocks/09/indian-stock-market.asp

${ }^{10}$ As section 4.1 explains, the knowledge capital variable was constructed using R\&D data. Though we started off with R\&D data on 380 firms for the period 2000-2010, the first observation was lost in constructing the knowledge capital variable, leaving us with data for 2001-2010.

${ }^{11}$ Varying these thresholds did not change the results qualitatively - the signs and significance of the variables of interest remained unchanged.
} 
relating to 380 firms, an average of 9.2 years per firm. ${ }^{12}$ The firms were spread across 22 manufacturing industries (mostly) at the broad 2-digit and (some at the) 3-digit levels of the National Industrial Classification (NIC). The list of industries and the number of firms in each is shown in Appendix A.

The market value of firms was computed as the sum of equity and the book value of debt.13 Physical capital was measured as the book value of net fixed assets. Knowledge capital, other intangible capital, and the quality measure were computed as described in the next three sections.

\subsection{Measuring knowledge capital}

We construct the stock of knowledge capital from the flow of R\&D expenditure using the usual perpetual inventory relation (Hall 1990):

$K_{K t}=(1-\theta) K_{K(t-1)}+R D_{t}$

where $K_{K}$ is the stock of knowledge capital, $R D$ is research and development investment, $\theta$ is the rate of depreciation of knowledge capital, and $t$ is the time subscript. To employ this relation, we need to resolve a number of issues. First, it is difficult to determine an appropriate rate of depreciation for knowledge capital, and we follow the literature in employing a rate of $15 \%$ per annum. Later in the paper we use 30\% per annum as a robustness check. Second, if there are only one or two missing values in the R\&D series for a firm, we interpolate these, since even a single missing value for R\&D for a firm will cause all the associated stocks to be missing. Third, to derive the value of the stock in the 'first' period, we divide the R\&D investment in that period by the sum of the rate of depreciation of knowledge capital and the pre-sample rate of growth of $R \& D$. We employ the sample period $R \& D$ data (along with the few pre-sample observations that are available for some firms) to compute a proxy for the pre-sample rate of growth of R\&D. This proxy is the average of R\&D growth rates within each of the 22 industries; the values are shown in Appendix A. With the exception of a few outliers based on very small samples, they range from $0.5 \%$ for metals to $2.7 \%$ for pharmaceuticals (compared to the $8 \%$ per annum that Hall (1990) suggests for the U.S.). Having computed the value of the stock in the first period, we then

\footnotetext{
12 The fact that we start with 380 firms and end up with 380 firms is purely coincidental. Splitting due to gaps or outliers in the data gives us 400 firms, but dropping firms with fewer than 3 observations reduces that to 380 firms.

${ }^{13}$ Using the methods suggested by Lewellen and Badrinath (1997), Hall and Kim (2000) showed that variations in the measurement of capital and debt that adjust for past inflation make little difference to the measured coefficients of R\&D stock in the Tobin's $q$ equation.
} 
employ equation (7) to derive the complete series, using R\&D data deflated by the industry sales deflator.

\subsection{Measuring other intangible capital}

The stock of other intangible capital $\left(K_{O I}\right)$ is approximated in terms of the firms' advertising expenditure, using the perpetual inventory relation. However, since such capital is subject to relatively rapid depreciation in comparison to knowledge capital, following Hall (1993) we take depreciation to be $30 \%$ per annum, ${ }^{14}$ and employ the sample period rate of growth of advertising expenditure to capitalize the first period of advertising expenditure. The latter is found to range between $-1.0 \%$ per annum and $2.7 \%$ per annum across the 22 industry groups. Having derived the first period stock of advertising capital (using the same methodology as that outlined in the previous sub-section for knowledge capital), we then derive the advertising capital series for each firm in the sample using the perpetual inventory equation and deflated advertising data.

Because the advertising expenditure variable is zero for about 40 per cent of the observations, in the regressions we also include a dummy for zero advertising, to check whether these firms are somehow different from the others. The coefficient of this variable was invariably insignificant, leading us to conclude that these firms look no different from those that did indeed have zero advertising that was captured well by the zero stock measure of advertising capital.

\subsection{Measuring the efficacy of intangible capital}

Although R\&D-based measures of the stock of knowledge capital may reflect the importance of the associated innovations better than patent-based measures, there may still be need to control for the efficacy of the R\&D output; for a given amount of $R \& D$ expenditure by different firms may not all be the same, if only because it may be spent in different ways. As a first pass, we propose to capture the efficacy of capital $(E)$ by the post-tax profit of firms in excess of that predicted by its capital stocks. Because current profit is itself likely to be influenced by the stocks of knowledge capital and other intangible capital of the firm, we regress the ratio of posttax profit to physical capital on the ratios of knowledge capital and other intangible capital to physical capital (as well as a full set of year dummies), and then take the residual from this

${ }^{14}$ Bagwell's (2007) review reports that Peles (1971), Palda (1964) and Telser (1962) suggest firm-level depreciation rates of advertising between $15 \%$ and $50 \%$ per annum for certain industries, whereas Lambin (1976) suggests an average depreciation rate of about $50 \%$ for brand advertising, supporting our use of an overall average of about $30 \%$. We experimented with a rate of $60 \%$ and found that the other results were largely unchanged, while the advertising capital coefficient rose to the level of the R\&D coefficient (results available on request). This suggests that advertising depreciation may indeed be quite high. 
regression as a proxy for the unobserved efficacy of capital. ${ }^{15}$ This measure also accounts to some extent for (semi-)permanent differences in managerial capabilities, human capital, and intangible assets besides those created by R\&D and advertising across firms, all of which contribute to the efficacy of the firm's capital stocks.

\subsection{Sample statistics}

Summary statistics for each of the variables are presented in Table 1 . To facilitate the comparison, we use the recent studies of Hall and Oriani (2006) for Europe, and Chadha and Oriani (2009) for India. We find the so-called Tobin's average $q\left(V / K_{P}\right)$ to be 4.4 on average, which is much larger than the magnitudes reported by Hall and Oriani for the UK, France, Germany and Italy, and even larger than that for the US. It is also larger than the 2.4 found by Chadha and Oriani for the earlier period in India, which doubtless reflects shifting expectations about firm growth following the various economic liberalizations of the 1990s.

The ratio of knowledge capital to physical capital $\left(K_{K} / K_{P}\right)$ is small, averaging 0.12 , as one would expect for a country where firms do not invest a great deal in R\&D. It is no surprise then, that this figure is only about one-fourth or one-third that for the US, Germany and France, although it is about the same as that for the UK, and it is much larger than the 0.03 reported by Chadha and Oriani for 1991-2005.16 The mean ratio of advertising capital to physical capital $\left(K_{O I} / K_{P}\right)$ is fairly high at 0.17 , exceeding those for the US, UK, Germany, and Italy, although the category of advertising capital is quite ill-defined and can vary across different accounting systems, making comparison difficult. The mean of the profit surprise to physical capital ratio $\left(E / K_{P}\right)$ is zero by construction, but it is slightly skewed to the left with a median of -0.03 ; as this is a novel measure, we have no comparators.

That most of the variables in question have highly skewed distributions becomes evident from considering their median values. At 3.2, the median value of Tobin's average $q$ is much smaller than its mean. The median ratio of the stock of knowledge capital to physical capital is a mere 0.05 , and that of the stock of advertising capital to physical capital even smaller at 0.0 , largely because many of the firms report no spending on advertising at all. The correlation matrix suggests a positive association between market value and the intangible capital variables, while discounting the possibility of any significant collinearity between the regressors.

\footnotetext{
15 Real post-tax profit is derived as post-tax profit deflated by the (industry-specific) wholesale price index for output.

16 Their sample contains 219 firms and is for a slightly earlier period, so that differences are to be expected.
} 
The final column in the table of means shows that with the exception of the efficacy variable and possibly the dependent variable, all the variables exhibit much higher variance across firms than within firms. This fact affects the identifiability of models based on within-firm data, and we will return to this issue after we present some of these results.

\section{Empirical Results}

\subsection{Econometric issues}

Several issues arise when estimating market value equations using panel data. The first is the presumed presence of permanent (or slowly changing) differences across firms that may be correlated with the regressors. The second is the fact that the capitals on the right hand side are at best predetermined and may even be contemporaneously correlated with the disturbances. The latter problem, although present in principle, is not an issue once it is recognized that the market value relationship is a hedonic one that describes the current equilibrium of supply and demand for claims on the underlying assets, and as such should be interpreted as a conditional expectation of price given the associated assets of the firm. Thus, the contemporaneous capitals will be uncorrelated with the disturbances by construction.

The seminal paper in hedonic price theory is Rosen (1974), which discusses the theoretical basis for interpreting the observed equilibrium price function for differentiated products. He shows that if buyers are identical but sellers differ in their characteristics, the observed prices as a function of characteristics traces out the demand for those characteristics. Symmetrically, if sellers are identical but buyers differ in their characteristics, observed prices trace out the supply function for the characteristics. In our setting here, the characteristics are the assets of the firm, the buyers are investors choosing firms that are made up of varying bundles of assets and the sellers are the firms. If we assume that stock markets incorporate information efficiently, then effectively all investors are alike in the data we observe, which implies that the hedonic price function we observe for R\&D capital is the demand function for such capital. This argument is reinforced by the fact that the capitals are very slow to adjust, while the market value is determined instantaneously in the stock market.

To return to firm effects, the usual solution to the problem of left-out firm characteristics offered in the literature is the use of estimation methods that control for permanent differences across firms. However, these methods to some extent violate the spirit of the hedonic model, whose identification is based on variations across firms in the bundles of assets they possess. A second issue is the well-known fact that within-firm R\&D and intangible investments tend to be

highly correlated over time, leading to even more highly correlated R\&D capital and other 
intangible capitals, which leaves little variation in these variables to explain shifts in market value after firm effects are removed. Even small amounts of measurement error can, therefore, cause large downward biases in the estimated coefficients (Griliches and Hausman 1986). A second problem is that fixed effects estimation itself is inconsistent in the presence of predetermined right hand side variables, and the solution to both problems is to use GMM estimation on a first-differenced version of the model, with lagged values of the variables as instruments (Arellano and Bond 1991, Blundell and Bond 2000). This ensures that noncorrelation between the dependent variable and future values of the independent variables is allowed, permanent firm effects are removed, and transitory measurement error is instrumented.

Unfortunately, in the case of the market value equation (unlike production functions), it has proved impossible in the past to find suitable instruments among the lagged variables in the model. For all these reasons, and because including firm dummies is inappropriate when estimating a pure hedonic model, our preferred estimates are those based on specifications without firm dummies, even though we also present estimates including fixed and random firm effects, in addition to some exploratory GMM estimates.

\subsection{Nonlinear Specification}

We first present the estimation results using equation (4), where the parameter estimates are derived using nonlinear least squares. The results are reported in Table 2. All regressions allow for year fixed effects, and report robust standard errors. Not surprisingly, the null hypothesis that all slopes are simultaneously zero is strongly rejected for all regressions. Column (1) shows that the (normalised) stock of knowledge capital $\left(K_{K} / K_{P}\right)$ has a strongly significant positive association with Tobin's $q$ (measured as $V / K_{P}$ ). Inclusion of the advertising capital variable $\left(K_{O I} / K_{P}\right)$ in the column (2) regression, and the efficacy variable $\left(E / K_{P}\right)$ in the column (3) regression, weakens the results somewhat. In addition, both the added regressors are also found to be strongly associated with market value, whereas the dummy for no advertising and the scale parameter are insignificantly different from zero. Thus, we find constant returns to scale in the basic market value relationship. The inclusion of the 22 industry dummies in column (4) reduces the R\&D coefficient by about one quarter, but leaves the advertising capital coefficient largely unchanged.

This table also shows the estimated elasticities for R\&D capital and advertising capital below the coefficient estimates. Both these elasticities and their standard errors are computed using the formula in equation (6) and the "delta" method, observation by observation, and then averaged over all observations. Taking column (3) as an example, the elasticity of market value with 
respect to R\&D capital has a mean value of 0.13 with a standard error of 0.02 , although the median is much lower at 0.07 with a standard error of 0.01 (not shown). The implication of the estimates in this table is that on average, doubling $R \& D$ is expected to increase value by about 11-14 per cent, which is very roughly equivalent to the average $R \& D$ capital share, implying a normal rate of return to R\&D. In contrast, advertising capital has an average elasticity of about 0.05-0.06, which is considerably less than the advertising share, although this interpretation is clouded by the number of zeroes in this variable.

In column (5) of Table 2, we present results for a regression with all the variables lagged one period, in order to assess the extent of bias due to transitory measurement error and simultaneity. With the exception of the R\&D coefficient, which declines by about 7 per cent, the results are largely unchanged (compare column 3 with column 5). In column (6), we present instrumental variable (IV) estimates with the lagged variables as instruments. The estimated $R \& D$ coefficient is approximately the same as in column (3), but the advertising capital coefficient is lower, and the efficacy variable coefficient is higher. We conclude that transitory measurement error and endogeneity are more likely to affect advertising and efficacy than the R\&D capital variable.

In the bottom panel of the table we have reported the average of the within-firm Durbin-Watson statistics. These are valid in this context, given the large sample size in the cross-section dimension. They suggest that substantial serial correlation remains in the disturbances even after inclusion of the measure of profit surprise. We will explore this symptom of misspecification later in the paper after we present the results of estimating the linear version of the model.

\subsection{Linear Specification}

Table 3 presents the results of estimating the model in equation (5) for the same set of specifications as in Table 2. Although the coefficient estimates are different because the specification is different, the main features of the estimation are the same. The average elasticity of market value with respect to advertising is roughly the same as in the nonlinear case, whereas the elasticity with respect to $R \& D$ capital is somewhat lower, around 0.12 for the instrumental variable estimates, as compared with 0.14 in the nonlinear case. There is still substantial serial correlation in the residuals, and the standard error of the estimate is approximately 0.56 , implying that unexpected movements in market value have a standard deviation of $56 \%$. This last result is similar to estimates that have been obtained for other countries. 


\subsection{Estimation with firm effects}

In Table 4 we present various estimates of the linear model that allow for firm effects. For these and subsequent estimations we dropped the zero advertising dummy, as it was always insignificant and it does not vary much within firm. The first column shows the estimates with two-digit industry effects only, for comparison. The next two columns are those for conventional fixed and random effects models. Compared to those with industry effects only, they show the downward bias in the coefficients that is customary when working with firm panel data, higher for fixed effects than random effects, of course. This implies correlation between any left out differences among firms and the included independent variables, but it may also imply measurement error in the independent variables, whose impact is larger in the within-firm dimension.

Including firm effects also reduces the residual serial correlation, but it is still quite significant. In an effort to model this feature of our data, in columns (4) and (5) we show estimates of a dynamic panel model that includes the lagged dependent variable. Column (4) has the usual fixed effects model, which is well-known to be inconsistent in this case (Blundell and Bond 2001), while column (5) shows GMM-SYS estimates, where the level equation is instrumented with first differences of lagged variables and the first-differenced version of the equation is instrumented by lagged level variables. Clearly the fixed effects model does eliminate much of the serial correlation. In principle, the GMM estimates would be consistent for our underlying model, provided they pass two specification tests: non-correlation of the lagged instruments with their contemporaneous residuals (the $\operatorname{AR}(2)$ test in the table), and the over-identification test due to Sargan. Here we use Hansen's robust variant of the test for over-identification. It is apparent that the Hansen test fails dramatically, and the residuals are slightly correlated at lag 2 (p-value $=0.05)$.

In Appendix B, we explore various versions of the GMM system estimation in an attempt to find a set of instruments that can pass the over-identification test, but without success. The version with the lowest Sargan test (adjusted for degrees of freedom) is the one we report in Table 4. Long run R\&D and advertising coefficients for this version of the model (the estimated coefficient divided by one minus the lagged log dependent variable coefficient) are slightly higher than those obtained with instrumental variable estimation (1.03 and 0.50). The scale coefficient is once again insignificant, contrary to the fixed effects estimates where it was strongly downward biased. Based on these explorations, our conclusions are twofold: first, in general it is not possible to obtain consistent estimates of the market value equation using the GMM panel methodology; and second, nevertheless, and taking all the results together, transitory measurement error does not affect the cross-section estimates very much although it 
does tend to bias the within firm estimates downward (compare OLS and IV without firm effects).

\subsection{Economic significance}

Analysis of the estimates can be done in several ways and we focus on the two most common: 1) coefficient estimates or semi-elasticities, and 2) the implied elasticities. Let us consider the latter first. As we showed in section 2 of the paper, the elasticity of Tobin's $q\left(V / K_{P}\right)$ with respect to the $\mathrm{R} \& \mathrm{D}$ capital intensity $K_{K} / K_{P}$ is given by $\beta K_{K} / K_{P}$ in the linear model and by $\sigma \beta\left(K_{K} / K_{P}\right) /\left(1+\beta K_{K} / K_{P}+\gamma K_{O I} / K_{P}+\delta S / K_{P}\right)$ in the nonlinear case. The implication in both cases is that the elasticity depends on the level of R\&D capital relative to tangible capital. In the nonlinear case, the equation allows for the fact that the total value of the capital is based significantly on the intangibles as well as on the tangibles, so the denominator of the term differs. In contrast, the linear model assumes that capitals other than tangible are small and do not affect the total capital measure very much. Because these elasticities depend on the R\&D capital intensity, it is necessary to choose a summary statistic when presenting the results. We have chosen to use the average elasticity in the sample. In the linear case, this is just the elasticity evaluated at the average R\&D capital intensity, but in the nonlinear case, it is the average over the sample of equation (6). These average values, together with the average standard errors, are shown in Tables 2 to 4 , below the coefficient estimates for R\&D capital and advertising capital, respectively.

The elasticity estimates pertaining to knowledge capital are fairly consistent across the alternative linear and nonlinear specifications, although somewhat lower in the linear model, as is evident from Tables 2 and 3. Controlling for advertising capital and efficacy, the magnitude of the average estimates ranges from 0.11 to 0.14 , with the nonlinear IV estimate of 0.14 . This implies that a doubling of the knowledge capital stock (per unit of physical capital) would lead to an increase in market value of approximately $14 \%$, which is somewhat greater than the R\&D capital share in total capital (0.12). ${ }^{17}$ However, comparing these elasticities with those for other countries would be problematic in the present context, because they would suffer from a 'level effect' given that the average stock of knowledge capital (at which these elasticities are computed) tends to vary significantly across countries.

In other words, comparisons ought to be made on the basis of coefficient estimates or semielasticities. How do these estimates of ours compare with those reported for the US and other developed countries? Take equation (1) with the scale coefficient $\sigma$ equal to unity as the basic

17 The corresponding advertising capital elasticity ranges from 0.04 to 0.06 , although this variable is so highly skewed and has so many zero values that the median elasticity is zero. 
relation implied by the theory in Hayashi (1982) and Hayashi and Inoue (1991). ${ }^{18}$ In equilibrium, and assuming correct measurement of the capitals, we expect two things to be true: first, adding a dollar (or rupee) to any of the capitals should raise market value by one dollar (or rupee); and second, overall Tobin's $q$ should be unity. The implication of these assumptions is that $p, \beta$, and $\gamma$ should all be equal to unity. Of course, the market is never in equilibrium, and our choice of capital measures is not perfect, but this is a useful baseline against which to compare the estimates for different countries, as it can be informative about the market for intangible assets and about the depreciation rates we use to construct them.

For US data, Hall et al. (2005) report R\&D capital coefficients of 1.74 for the 1976-1984 period, and 0.55 for the 1985-1992 period. Using a slightly different formulation with beginning of year capitals and a larger dataset, Hall (2005) reports coefficients ranging between 0.4 and 0.8 for the 1974-2003 period, and Hall and Oriani (2006) report 0.8 for the $1989-1998$ period. The conclusion reached in Hall (2005) is that the primary reason that these coefficients are biased downwards from unity is that the depreciation rate used to construct R\&D capital is too low in some sectors, notably the information technology sectors where technical change has been quite rapid due to Moore's Law and the falling price of semiconductors over the period. The relatively high coefficient for 1976-1984 may be explained by some data problems during that period, due to the phase-in of $R \& D$ reporting, as well as disequilibrium in the market for these assets (that is, lack of sufficient R\&D investment).

Hall and Oriani (2006) also report estimates of the R\&D capital coefficient for France, Germany, Italy, and the UK for the 1989-1998 period. These are quite variable, ranging from insignificant for Italy to 1.92 for the UK (for France, Germany, and the US they are $0.41,0.36$, and 0.80 respectively). The UK estimate is the closest to that for Indian firms, which is 1.76 (standard error 0.33) based on instrumented nonlinear least squares (column 6 of Table 2). Estimates of this magnitude carry the strong implication that there may be underinvestment in R\&D in these countries, because increasing R\&D would more than pay for itself in market value increases. The result itself implies either that the $15 \%$ depreciation rate used to construct R\&D capital was too high (which is unlikely) or because the market requires a much higher rate of return to capital for R\&D-intensive firms than for other firms, probably because of risk and uncertainty. The question then is why the markets in these countries, the UK and India, but not in other countries, behave in this way.

18 Many critics have pointed out that this functional form ignores the fact that there may be interaction effects among the capitals, which is true. It is best considered as a first order approximation to a more complex valuation formula. In practice, interaction effects tend to be extremely imprecisely measured. 
If indeed there is underinvestment in R\&D by Indian firms, that could be the result of several different factors. One important factor could be the unwillingness to do so, given the risk attaching to R\&D projects (Day 2007); it is possible that such risk is more binding below some size threshold (Coad and Rao 2010). Another factor could be the inability to do so, given lack of adequate access to finance (Brown, Martinsson, and Petersen 2012), signaled by a high required rate of return to R\&D. A third factor might be inadequate competition in the relevant product markets; such competition has a tendency to reduce profit rates, and innovation is seen as a mechanism for escaping such competition (Griffith, Harrison and Simpson 2010). Finally, there is some evidence that weak intellectual property protection, if only due to lax implementation, may discourage innovation (Hudson and Minea 2013).

Although the focus of this paper is on R\&D spending, we have also estimated the coefficient of advertising capital, with the estimation based on a fairly high depreciation rate of $30 \%$. A typical estimate from the nonlinear model is approximately 0.8 , which suggests undervaluation or a more rapid depreciation rate than we used to construct the variable. We can compare this estimate to some for the US. For example, Servaes and Tamayo (2013) estimate a Tobin's $q$ regression with advertising intensity (a flow measure) and a measure of corporate social responsibility (CSR) for US firms during the 1991-2005 period, obtaining an average coefficient of about 5.5 (corrected for the average level of CSR). Converting this flow coefficient to a stock coefficient of unity (the theoretical value) would require a depreciation rate of 18 per cent, somewhat lower than what we used. Hirschey and Weygandt (1985), using data for 1977, obtain depreciation (amortization) rates for advertising that are very similar to those for R\&D. On the other hand, Hall (1993b) uses a large sample of US firms for the period 1973-1991 and obtains an advertising coefficient that is one-quarter to one-third that for R\&D, which suggests a much higher depreciation rate. However, she also shows yearly estimates that increase steadily to parity at the end of the period, consistent with the Servaes and Tamayo result.

\section{Variation Across Sectors}

One of the important determinants of variations in R\&D intensity is variation across industrial sectors in the importance of $R \& D$ spending that is internal to the firm. Thus, it is useful to look at the market valuation of intangible assets at a more disaggregated level. We chose to classify our sample firms into the four groups described by Pavitt (1984):19 (1) supplier dominated industries, (2) production intensive (scale intensive) industries, (3) production intensive specialised suppliers industries, and (4) science-based industries. The precise classification is

\footnotetext{
${ }^{19}$ See also Greenhalgh and Rogers (2006).
} 
given in Table A1. The idea behind this typology is the contention that although firms vary in their technological trajectories, there is still sufficient basis to group them in a meaningful manner. For example, Pavitt (1984) identifies groups (2) and (4) as those primarily concerned with in-house R\&D, whereas group (1) innovates by acquiring new process technology, and group (3) is more dependent on customers for product design and development. In our data, there is a somewhat different pattern: the $R \& D$ and advertising capital intensities for the four groups are the following:

\begin{tabular}{|l|c|c|}
\hline \multicolumn{1}{|c|}{ Pavitt Sector } & $\begin{array}{c}\text { R\&D to Physical Capital } \\
\text { ratio }\end{array}$ & $\begin{array}{c}\text { Advertising to Physical Capital } \\
\text { ratio }\end{array}$ \\
\hline Supplier-dominated industries & 0.041 & 0.094 \\
\hline Scale-intensive industries & 0.093 & 0.247 \\
\hline Specialised-suppliers industries & 0.153 & 0.043 \\
\hline Science-based industries & 0.161 & 0.083 \\
\hline
\end{tabular}

Evidently, the specialized suppliers in this sample are more R\&D-oriented than was contemplated by the Pavitt classification. In addition, the scale intensive firms are also highly advertising intensive, which turns out to be due primarily to the brand-oriented personal care industry. Otherwise, the ranking of sectors is as we might have expected.

Table 5 presents the nonlinear estimation results including R\&D capital, advertising capital, and the profit surprise. We discuss the results for each Pavitt sector in turn. Group (1) is relatively small, with only 32 firms, most of which are in textiles. For this group, the R\&D capital coefficient is large and extremely imprecisely determined, whereas the advertising capital coefficient is large and fairly significant. Apparently these low-tech supplier-dominated firms are quite heterogeneous in their R\&D behavior (e.g., Bata, a shoe manufacturer, has quite high $R \& D$, whereas most other firms in the sector have very little), and in its valuation. Because most of their production is consumer-oriented, advertising is quite important and valued.

The other 3 groups have significant and similar R\&D capital coefficients, somewhat lower for the specialized suppliers. The average elasticities of market value with respect to R\&D capital are in fact roughly equal to the R\&D capital shares in the table above, which does not suggest underinvestment. The advertising capital coefficients are more variable, with that for the specialized suppliers insignificant. The others are fairly precise and the average elasticities are roughly consistent with the advertising capital shares. The coefficient of the efficacy variable is remarkably consistent across the sectors, which implies that valuation of success or failure at achieving returns from the various firm assets is neutral across sectors. 


\section{Risk and Uncertainty}

More than one researcher has emphasized that the uncertainty associated with the outcome of $R \& D$ programmes implies that the right way to value $R \& D$ is to use a real options approach that recognizes the option value of continuing or shutting down the various projects (Bloom and Van Reenen 2002, Oriani and Sobrero 2008). These two papers take different approaches: Bloom and Van Reenen (2002) focus on the valuation of patents and the associated option value of waiting to bring the product to market, whereas Oriani and Sobrero (2008) build a more complex model of multiple real options, due to both market (demand) uncertainty and technological uncertainty. Bloom and Van Reenen's model predicts both that profit uncertainty and its interaction with R\&D or patent intensity will increase market valuation, because higher volatility increases the likelihood that expected profit from investing in development will cross the profitability threshold. However, their empirical results, based on UK firm data from 1986 to 1996, do not support this prediction, and they suggest that other causes of uncertainty, such as increased costs of capital, may be the source of the negative coefficients.

Oriani and Sobrero identify three options arising from R\&D: the growth option, the option to switch, and the option to wait. The growth option is similar to that described by Bloom and Van Reenen, and is positively affected by market uncertainty. The option to switch is affected only by technological uncertainty, whereas the option to wait increases with both types of uncertainty. Although all these options suggest positive valuation for volatility or uncertainty, the basic net present value of profit flows from the firm's activities is affected negatively by uncertainty, due to the higher discount rates applied to evaluate it. They use this model to predict a U-shaped relationship between market uncertainty and market valuation of R\&D, and an inverse U-shaped relationship between technological uncertainty and market valuation of R\&D. Their results, based on data for UK firms from 1989 to 1998, confirm these relationships.

These two papers used a range of methods to measure firm-level volatility. Bloom and Van Reenen (2002) used a firm-specific measure of the variance of profits or the stock market return, with similar results. Oriani and Sobrero (2008) measured market uncertainty using a GARCH autoregressive model of industry output, and computed uncertainty as the absolute value of the difference between actual and predicted industry output that year. Technological uncertainty was measured using the technology cycle time developed by CHI Research (Narin 1999). Owing to data limitations, we have chosen to investigate the role of uncertainty using a slightly different uncertainty measure, but one in the spirit of the market uncertainty measures described above.

Our measure of uncertainty is based on a GARCH model whose estimates are reported in Appendix Table B3. We model the logarithm of sales as a function of its lag and the year 
dummies, and then allow the variance of the disturbance in this model to evolve as a GARCH process, where the coefficients depend on firm size (as measured by the log of net fixed assets). We then average the estimates of the variance of this model over industry and year, and include these in our basic market value model as a control for market uncertainty in that industry and time period.

Let $y$ denote the log of sales, $x$ the log of net fixed assets $\left(K_{P}\right)$, and $j$ the industry to which the $i^{t h}$ firm belongs. Then our full GARCH model is:

$y_{i t}=\mu_{t}+\beta_{1} y_{i, t-1}+\varepsilon_{i t}$

$\varepsilon_{i t} \sim \Phi\left(0, h_{i t}\right)$

$h_{i t}=\exp \left(\mu_{j}+\alpha_{1} x_{i t}\right)+\left(\pi_{0}+\pi_{1} x_{i t}\right)\left(\hat{\varepsilon}_{i, t-1}\right)^{2}+\left(\gamma_{0}+\gamma_{1} x_{i t}\right) h_{i, t-1}$

where $\mu_{t}$ are the year dummies, and $\mu_{j}$ the industry dummies. We estimate this model by maximum likelihood on the pooled panel. Note that unlike the usual GARCH model, identification here rests on the cross-section variation rather than on the time series variation, as our panel is quite short. ${ }^{20}$ In practice, we found that the coefficients of $x$ (log of net fixed assets) were insignificantly different from zero in the $\hat{\varepsilon}_{t-1}^{2}$ and $h_{t-1}$ terms (i.e., the second and third terms on the right hand side of equation 8c), and so we dropped those coefficients. Our preferred estimates were the following:

$y_{i t}=\mu_{t}+1.00 y_{i, t-1}+\varepsilon_{t}$

$h_{i t}=\exp \left(\mu_{j}-0.24 x_{i t}\right)-0.06\left(\hat{\varepsilon}_{i, t-1}\right)^{2}+1.08 h_{i, t-1}$

These estimates imply several things: (1) sales appears to evolve as a simple random walk; (2) the variance of the sales process is highly serially correlated and growing, with the growth dampened slightly by the actual draw on the disturbance variance in the previous period; (3) the variance varies across industry (compare columns (4) and (5) in Table B2); and (4) the variance is declining in firm size as measured by net fixed assets.

Given these estimates, we computed the industry-year means of the variance $h$ predicted by the model and included them in our market value regression, both alone and interacted with the R\&D capital variable. The results, estimated by NLLS with robust standard errors clustered on the firm, are presented in Table 6. The sample size is slightly different from that in Table 3 due to the need to use lagged values in the model, so column (1) simply repeats the regression in column (3) of Table 3. Column (2) shows that the industry average sales variance enters

\footnotetext{
${ }^{20}$ Brownlees (2013) suggests estimating such a model for financial institutions during 2007-2009, where the panel dimension is quite short.
} 
positively in the market value equation, as predicted by the real options theory, albeit with a large standard error. The average value of this variable is 0.02 , with a standard deviation of 0.01. Therefore, this result implies that a one standard deviation increase in the industry average sales variance is associated with about a 10 per cent increase in the market value of the firms in that industry, other things equal, which seems both plausible and non-negligible. However, the standard error on this prediction is also large, on the order of 5.7 per cent, so the exact magnitude of the result is somewhat uncertain.

This imprecision carries over to columns (3) and (4), where we investigate the shape of the relationship and the interaction with R\&D. Neither effect is significant, and the standard errors are very large, so the estimates neither confirm nor rule out such a relationship. There is a slight hint that firms with higher R\&D intensity receive a somewhat lower premium from uncertainty, which may indicate that they face higher discount rates or costs of capital, as suggested by both Bloom and Van Reenen (2002) and Oriani and Sobrero (2008). Column (4) also shows that the inclusion of the interaction effect reduces the raw R\&D capital coefficient slightly but insignificantly, consistent with an interpretation that the size of this coefficient is partly due to the option value of R\&D.

\section{Conclusion}

This paper revisits the relationship between market valuation and innovation in the context of manufacturing firms in India, using recent data for the period 2001 to 2010. The goal was to examine whether and how financial markets in a fairly sophisticated developing economy were valuing innovation investments, and whether there appeared to be over- or under-investment in $R \& D$ in Indian manufacturing firms. We found that the stock market does value the $R \& D$ capital created by these firms, and that the magnitude of the premium appears to be larger than that reported by studies on developed economies, with the exception of some estimates for the UK. There are several possible interpretations of this result. The first and most obvious is that the depreciation rate used to construct R\&D capital was too high (Hall 2005), leading to values of the independent variable that were too low. But this is unlikely, because other studies have found higher depreciation rates in most sectors in other countries.

A second explanation is that Indian firms underinvested in $R \& D$ for some reason, or that $R \& D$ turned out to be more profitable ex post than was predicted ex ante, during this period. The high valuation of $R \& D$ assets may simply be signaling that Indian firms should be undertaking more because their prospects have improved, and because of the need to find suitable scientists and engineers, etc., adjustment to the high rate of return via expanded investment is not instantaneous. This is certainly a possibility worth exploring in future work. It is consistent with 
what was observed in the United States during the period when $R \& D$ became salient to financial investors because of changes in reporting requirements (1970s-1980s). During these years in the U.S., the marginal value of an R\&D dollar to a publicly traded firm declined towards unity and even below as more firms entered the R\&D and/or R\&D-reporting activity. A third possibility, for which we found weak support, is that R\&D-intensive firms are valued more highly due to the option value of R\&D programs. In assessing this possibility it is useful to recall that our sample consists only of R\&D firms, so that our finding of a positive association with a risk measure could indeed be related to the fact that they perform R\&D. India may be different, but it seems unlikely to differ in that way.

Looking across sectors using the industry groupings due to Pavitt, we actually found relatively little variation in the coefficients of the market valuation that was significant. The supplierdominated sector, a low-tech manufacturing sector, showed some differences, but it was a very small sector and the differences from the other sectors were largely insignificant. The one implication we can draw from this result is, that the allocation of R\&D across sectors is not obviously inefficient in India. 


\section{References}

Altenburg, Tilman and Hubert Schmitz, 2008, Breakthrough? China's and India's Transition from Production to Innovation, World Development, 36(2), 325-344.

Arellano, Manuel, and Stephen R. Bond, 1991, Some Tests of Specification for Panel Data: Monte Carlo Evidence and An Application to Employment Equations, Review of Economic Studies 58 (2), 277-297.

Athreye, Suma and Sandeep Kapur, 2009, Introduction: The Internationalization of Chinese and Indian Firms - Trends, Motivations and Strategy, Industrial and Corporate Change, 18(2), 209-221.

Bagwell, Kyle, 2007, The Economic Analysis of Advertising, Ch. 28 in Mark Armstrong and Robert H. Porter (eds.) Handbook of Industrial Organization, volume 3, North-Holland, Amsterdam.

Bloom, Nicholas and John Van Reenen, 2002, Patents, Real Options and Firm Performance, Economic Journal, 112(478), C97-C116.

Blundell, Richard and Stephen R. Bond, 2000, GMM Estimation with Persistent Panel Data: An Application to Production Functions, Econometric Reviews 19(3): 321-340.

Blundell, Richard, Rachel Griffith, and John Van Reenen, 1999, Market Share, Market Value and Innovation in a Panel of British Manufacturing Firms, Review of Economic Studies, 66(3), 529-554.

Bogliacino, Francesca, Giulio Perani, Mario Pianta, Stefano Supino, 2012, Innovation and Development: The Evidence from Innovation Surveys, Latin American Business Review, 13(3), 219-261.

Brown, James R., Gustav Martinsson and Bruce C. Petersen, Do Financing Constraints Matter for R\&D?, European Economic Review, 56(8), 1512-1529.

Brownlees, Christian T., 2013, Cross Sectional Heterogeneity in GARCH Panels and Firm Characteristics: Evidence from the Financial Crisis, Available at SSRN http://ssrn.com/abstract=1695649 and http://dx.doi.org/10.2139/ssrn.1695649; accessed 26 January 2015.

Chadha, Alka, and Raffaele Oriani, 2010, R\&D Market Value under Weak Intellectual Property Rights Protection: The Case of India, Scientometrics, 82(1), 59-74.

Chittoor, Raveendra and Sougata Ray, 2007, Internationalization Paths of Indian Pharmaceutical Firms - A Strategic Group Analysis, Journal of International Management, 13(3), 338355.

Coad, Alex. and Rekha Rao, 2010, Firm Growth and R\&D Expenditure, Economics of Innovation and New Technology, 19(2), 127-145. 
Cockburn, Iain, and Zvi Griliches, 1988, Industry Effects and Appropriability Measures in the Stock Market's Valuation of R\&D and Patents, American Economic Review, 78(2), 419423.

Corrado, Carol, Charles Hulten, and Daniel Sichel, 2009, Intangible Capital and U. S. Economic Growth, Review of Income and Wealth 55(3), 661-685.

CMIE, 2012, Prowess: Release 4.11, <www.prowess.cmie.com>

Czarnitzki, Dirk, Bronwyn H. Hall and Raffaele Oriani, 2006, Market Valuation of US and European Intellectual Property, in Derek Bosworth and Elizabeth Webster (eds) The Management Of Intellectual Property, Cheltenham and Brookfield: Edward Elgar.

Day, George, 2007, Is It Real? Can We Win? Is It Worth Doing?, Managing Risk and Reward in an Innovation Portfolio, Harvard Business Review, 85(12), 110-125.

Ekeland, Ivar, James J. Heckman, and Lars Nesheim, 2004, Identification and Estimation of Hedonic Models, Journal of Political Economy 112 (1, pt.2), s60-s109.

Goldstein, Andrea, 2008, Multinational Companies from Emerging Economies: Composition, Conceptualization \& Direction in the Global Economy, Indian Journal of Industrial Relations, 45(1), 137-147.

Greenhalgh, Christine, and Mark Rogers, 2006, The Value of Innovation: The Interaction of Competition, R\&D and IP, Research Policy, 35(4), 562-580.

Griffith, Rachel, Rupert Harrison, and Helen Simpson, 2010, Product Market Reform and Innovation in the EU, Scandinavian Journal of Economics, 112(2), 389-415.

Griffiths, William, and Elizabeth Webster, 2006, Trends in the Value of Intellectual Property in Australia, in Derek Bosworth and Elizabeth Webster (eds.) The Management of Intellectual Property, Cheltenham and Brookfield, Edward Elgar.

Griliches, Zvi, 1981, Market Value, R\&D, and Patents, Economics Letters, 7(2), 183-187.

Griliches, Zvi, Bronwyn H. Hall and Ariel Pakes, 1991, R\&D, Patents, and Market Value Revisited: Is There a Second (Technological Opportunity) Factor? Economics of Innovation and New Technology 1(3), 183-202.

Griliches, Zvi and Jerry A. Hausman, 1986, Errors in Variables in Panel Data, Journal of Econometrics, 31(1), 93-118.

Hall, Bronwyn H., 2005, Measuring the Returns to R\&D: The Depreciation Problem, Annales d'Economie et de Statistique, 79-80 (Special Issue), 341-381.

Hall, Bronwyn H., 1993a, The Stock Market's Valuation of R\&D Investment During the 1980's. American Economic Review, 83(2), 259-264.

Hall, Bronwyn H., 1993b, The Value of Intangible Corporate Assets: An Empirical Study of the Components of Tobin's Q, UC Berkeley Dept. of Economics Working Paper No. 93-207. Berkeley, CA: University of California at Berkeley. 
Hall, Bronwyn H., 1990, The Manufacturing System Master File: 1959-1987, Working Paper no. 3366, National Bureau of Economic Research, Cambridge, Massachusetts.

Hall, Bronwyn H., Adam Jaffe and Manuel Trajtenberg, 2000, Market Value and Patent Citations: A First Look, Working Paper 7741, National Bureau of Economic Research, Cambridge, Massachusetts.

Hall, Bronwyn H. and Daehwan Kim, 2000, Valuing Intangible Assets: The Stock Market Value of R\&D Revisited. UC Berkeley, Nuffield College, Harvard University, and NBER. Available at http://eml.berkeley.edu// bhhall/papers/HallKim98 valuingR\&D.pdf

Hall, Bronwyn H. and Megan MacGarvie, 2010, 'he Private Value of Software Patents, Research Policy, 39(7), 994-1009.

Hall, Bronwyn H. and Raffaele Oriani, 2006, Does the Market Value R\&D Investment by European Firms? Evidence from a Panel of Manufacturing Firms in France, Germany and Italy, International Journal of Industrial Organization, 24(5), 971-993.

Hayashi, Fumio, 1982, Tobin's Marginal $q$ and Average $q$ : A Neoclassical Interpretation, Econometrica, 50 (1), 213-224

Hayashi, Fumio and Tohru Inoue, 1991, The Relation Between Firm Growth and Q with Multiple Capital Goods: Theory and Evidence from Panel Data on Japanese Firms, Econometrica, 59(3), 731-753.

Hirschey, Mark and Jerry J. Weygandt, 1985, Amortization Policy for Advertising and Research and Development Expenditures, Journal of Accounting Research, 23(1), 326-335.

Hudson, John and Alexandru Minea, 2013, Innovation, Intellectual Property Rights, and Economic Development: A Unified Empirical Investigation, World Development, 46(1), 66-78.

Jaffe, Adam B., 1986, Technological Opportunity and Spillovers of R\&D: Evidence from Firms' Patents, Profits, and Market Value, American Economic Review, 76(5), 984-1001.

Lambin, Jean-Jacques, 1976, Advertising, Competition and Market Conduct in Oligopoly over Time, North-Holland, Amsterdam.

Lamm Jr., R. McFall, 2010, Equity Returns in Emerging Markets: Prospects for the BRICs, in Greg N. Gregoriou (ed.) Emerging Markets: Performance, Analysis and Innovation, Taylor and Francis, London.

Lanjouw, Jean O., 1998, The Introduction of Pharmaceutical Product Patents in India: "Heartless Exploitation of the Poor and Suffering"?, Working Paper No. 6366, National Bureau of Economic Research, Cambridge, Massachusetts.

Lewellen, Wilbur G. and S. G. Badrinath, 1997, On the measurement of Tobin's q. Journal of Financial Economics 44(1), 77-122. 
Lei, Zhen, 2012, Chinese Patent System, presentation to the JRC-IPTS 4th workshop on The Output of R\&D Activities: Harnessing the Power of Patent Data, May 24-25, Seville. Accessed 26 January 2015 at http://is.jrc.ec.europa.eu/pages/ISG/patents/documents/LeiChinaPatentSystem.pdf

Mukhopadhyay, Debabrata and Nityanand Sarkar, 2003, Stock Return and Macroeconomic Fundamentals in Model Specification Framework: Evidence From Indian Stock Market, Economic Research Unit, Indian Statistical Institute (Kolkata), mimeo.

Narin, Francis, 1999, Tech-line Background Paper. Accessed 26 January 2015 at http://citeseerx.ist.psu.edu/viewdoc/download?doi=10.1.1.23.4124\&rep=rep1\&type=p $\underline{\mathrm{df}}$

Oriani, Raffaele and Maurizio Sobrero, 2008, Uncertainty and the Market Valuation of R\&D Within a Real Options Logic, Strategic Management Journal, 29(4), 343-361.

Palda, K.S., 1964, The Measurement of Cumulative Advertising Effects, Prentice-Hall, Englewood Cliffs, NJ.

Pavitt, Keith, 1984, Sectoral Patterns of Technical Change: Towards a Taxonomy and a Theory, Research Policy, 13(6), 343-373.

Peles, Y., 1971, Rates of Amortization of Advertising Expenditures, Journal of Political Economy, $79(5), 1032-1058$.

Rosen, Sherwin, 1974, Hedonic Prices and Implicit Markets: Product Differentiation in Pure Competition, Journal of Political Economy, 82(1), 34-55.

Saxenian, AnnaLee, 2002, Transnational Communities and the Evolution of Global Production Networks: The Cases of Taiwan, China and India, Industry and Innovation, 9(3), 183-202.

Servaes, Henri and Ane Tamayo, 2013, The Impact of Corporate Social Responsibility on Firm Value: The Role of Customer Awareness, Management Science, 59(5), 1045-1061.

Singh, Rajesh K., Suresh K. Garg and S. G. Deshmukh, 2007, Strategy Development for Competitiveness: A Study on Indian Auto Component Sector, International Journal of Productivity and Performance Management, 56(4), 285-304.

Tas, Oktay, Cumhur Ekinci, Kaya Tokmakcioglu, 2010, Indices and Price Book, Price Earnings, and Dividend Yield Ratios in Emerging Financial Markets, in Greg N. Gregoriou (ed.) Emerging Markets: Performance, Analysis and Innovation, Taylor and Francis, London.

Telser, Lester G., 1962, Advertising and Cigarettes, Journal of Political Economy, 70(5), 471-499. The Economist, 2010, The BRICs: The Trillion-Dollar Club, 395(8678), April 17, 2010, 59 61.

Toivanen, Otto, Paul L. Stoneman and Derek Bosworth, 2002, Innovation and the Market Value of UK Firms, 1989 - 1995, Oxford Bulletin of Economics and Statistics, 64(1), 39-62.

Topalova, Petia and Amit Khandelwal, 2011, Trade Liberalization and Firm Productivity: 
The Case of India, Review of Economics and Statistics, 93(3), 995-1009.

Wildasin, D. E., 1984, The q Theory of Investment with Many Capital Goods, American Economic Review 74(1), 203-10.

WIPO, 2014, World Intellectual Property Indicators, Accessed 26 January 2015 at http://www.wipo.int/edocs/pubdocs/en/wipo pub 941 2014.pdf 
Table 1

Sample statistics (3,494 observations on 380 firms, 2001-2010)

\begin{tabular}{|c|c|c|c|c|c|c|}
\hline Variable & Mean & Median & $\begin{array}{l}\text { Standard } \\
\text { Deviation }\end{array}$ & Minimum & Maximum & $\begin{array}{r}\text { Share Variance } \\
\text { Within }^{+1} \\
\end{array}$ \\
\hline$V / K_{P}$ & 4.36 & 3.23 & 3.43 & 0.16 & 19.82 & 0.265 \\
\hline$K_{K} / K_{P}$ & 0.12 & 0.05 & 0.20 & 0.00 & 2.72 & 0.159 \\
\hline$K_{K}^{\prime} / K_{P}$ & 0.17 & 0.06 & 0.32 & 0.00 & 5.39 & 0.181 \\
\hline$K_{O I} / K_{P}$ & 0.13 & 0.00 & 0.42 & 0.00 & 7.38 & 0.078 \\
\hline$E / K_{P}$ & 0.00 & -0.03 & 0.31 & -1.94 & 2.02 & 0.427 \\
\hline$K_{P}$ (M rupees) & $1140.7^{\dagger}$ & 1110.8 & 1.71 & 2.30 & $1,500,007$ & 0.050 \\
\hline \multirow[t]{3}{*}{$\mathrm{D}\left(K_{O I}=0\right)$} & $42.4 \%$ & & & & & 0.052 \\
\hline & \multicolumn{6}{|c|}{ Correlation Matrix } \\
\hline & $\ln \left(V / K_{P}\right)$ & $K_{K} / K_{P}$ & $K_{K}^{\prime} / K_{P}$ & $K_{O I} / K_{P}$ & $E / K_{P}$ & $\ln K_{P}$ \\
\hline $\ln \left(V / K_{P}\right)$ & 1 & & & & & \\
\hline$K_{K} / K_{P}$ & 0.330 & 1 & & & & \\
\hline$K_{K}^{\prime} / K_{P}$ & 0.338 & 0.906 & 1 & & & \\
\hline$K_{O I} / K_{P}$ & 0.302 & 0.112 & 0.077 & 1 & & \\
\hline$E / K_{P}$ & 0.391 & -0.004 & -0.140 & -0.001 & 1 & \\
\hline $\ln K_{P}$ & -0.024 & -0.131 & -0.045 & -0.039 & 0.004 & 1 \\
\hline
\end{tabular}

Definitions:

$V=$ Market value $=$ Equity + Book Debt

$K_{P}=$ Net fixed assets

$K_{K}=$ Knowledge capital at $15 \%$ depreciation

$K_{K}^{\prime}=$ Knowledge capital at $30 \%$ depreciation

$K_{O I}=$ Advertising capital at $30 \%$ depreciation

$E=$ Efficacy of capital $=$ Profit surprise

${ }^{\dagger}$ Geometric mean

${ }^{+\dagger}$ Within-firm variance as a proportion of total variance (controlling for overall year means) 
Table 2

Nonlinear Regressions

Dependent Variable: $\ln \left(V / K_{P}\right)$

\begin{tabular}{|c|c|c|c|c|c|c|}
\hline & $(1)$ & $(2)$ & (3) & $(4)$ & (5) & (6) \\
\hline Regressor & NLLS & NLLS & NLLS & NLLS & NLLS, lag RHS & NLIV \\
\hline \multirow[t]{4}{*}{$K_{K} / K_{P}$} & $2.275^{* * *}$ & $2.009^{* * *}$ & $1.790^{* * *}$ & $1.473^{* * *}$ & $1.661^{* * *}$ & $1.764^{* * *}$ \\
\hline & $(0.389)$ & $(0.375)$ & $(0.330)$ & $(0.336)$ & $(0.324)$ & (0.329) \\
\hline & {$[0.164]^{* * *}$} & {$[0.140]^{* * *}$} & {$[0.134]^{* * *}$} & {$[0.114]^{* * *}$} & {$[0.126]^{* * *}$} & {$[0.137]^{* * *}$} \\
\hline & $(0.018)$ & $(0.018)$ & $(0.018)$ & $(0.019)$ & $(0.018)$ & $(0.018)$ \\
\hline \multirow{4}{*}{$K_{O I} / K_{P}$} & & $0.988^{* * *}$ & $0.817^{* * *}$ & $0.974^{* * * *}$ & $0.815^{* * *}$ & $0.640^{* * * *}$ \\
\hline & & $(0.224)$ & $(0.183)$ & $(0.191)$ & $(0.185)$ & $(0.145)$ \\
\hline & & {$[0.058]^{* * *}$} & {$[0.052]^{* * *}$} & {$[0.059]^{* * *}$} & {$[0.051]^{* * *}$} & {$[0.044]^{* * *}$} \\
\hline & & $(0.009)$ & $(0.008)$ & $(0.008)$ & $(0.008)$ & $(0.008)$ \\
\hline \multirow[t]{2}{*}{$\mathrm{D}\left(K_{O I}=0\right)$} & & -0.028 & -0.037 & -0.004 & -0.031 & -0.083 \\
\hline & & $(0.057)$ & $(0.053)$ & $(0.056)$ & $(0.055)$ & $(0.053)$ \\
\hline \multirow[t]{2}{*}{$E / K_{P}$} & & & $0.508^{* * *}$ & $0.464^{* * *}$ & $0.527^{* * *}$ & $0.709^{* * * *}$ \\
\hline & & & $(0.103)$ & $(0.101)$ & $(0.095)$ & $(0.031)$ \\
\hline \multirow[t]{2}{*}{$\ln K_{P}$} & 0.020 & 0.020 & 0.012 & 0.015 & 0.013 & 0.012 \\
\hline & $(0.015)$ & $(0.015)$ & $(0.014)$ & $(0.015)$ & $(0.014)$ & $(0.016)$ \\
\hline Industry dummies & No & No & No & Yes & No & No \\
\hline Year fixed effects & Yes & Yes & Yes & Yes & Yes & Yes \\
\hline$R^{2}$ & 0.199 & 0.267 & 0.318 & 0.383 & 0.286 & 0.270 \\
\hline Standard Error & 0.608 & 0.582 & 0.561 & 0.536 & 0.571 & 0.579 \\
\hline Panel Durbin-Watson & 0.266 & 0.285 & 0.316 & 0.345 & 0.360 & 0.346 \\
\hline Observations & 3494 & 3494 & 3494 & 3494 & 3114 & 3114 \\
\hline Firms & 380 & 380 & 380 & 380 & 380 & 380 \\
\hline
\end{tabular}

Note: Robust standard errors clustered on firm in parentheses below each coefficient Elasticity at the means in square brackets, with its standard error below it In column (5), all right hand side (RHS) variables are lagged one year In column (6), the instruments are the right hand side variables lagged one year ,*** and ${ }^{*}$ denote significance at the $1 \%, 5 \%$ and $10 \%$ levels, respectively, for a two-tail test 
Table 3

Linear Regressions

Dependent Variable: $\ln \left(V / K_{P}\right)$

\begin{tabular}{lllllll}
\hline & $(1)$ & $(2)$ & $(3)$ & $(4)$ & $(5)$ & $(6)$ \\
\hline Regressor & OLS & OLS & OLS & OLS & OLS, lag RHS & IV \\
\hline$K_{K} / K_{P}$ & & & & & & \\
& $1.025^{* * * *}$ & $0.939^{* * *}$ & $0.943^{* * *}$ & $0.790^{* * *}$ & $0.912^{* * *}$ & $0.964^{* * *}$ \\
& $(0.136)$ & $(0.129)$ & $(0.116)$ & $(0.118)$ & $(0.118)$ & $(0.120)^{* * *}$ \\
& {$[0.128]^{* * *}$} & {$[0.117]^{* * *}$} & {$[0.117]^{* * *}$} & {$[0.098]^{* * *}$} & {$[0.114]^{* * *}$} & {$[0.118]^{* * *}$} \\
$K_{O I} / K_{P}$ & $(0.017)$ & $(0.016)^{* *}$ & $(0.014)$ & $(0.015)$ & $(0.015)^{* * *}$ & $(0.015)^{* *}$ \\
& & $0.368^{* * *}$ & $0.368^{* * *}$ & $0.393^{* * *}$ & $0.392^{* * *}$ & $0.385^{* * *}$ \\
& & $(0.062)$ & $(0.051)$ & $(0.055)$ & $(0.055)$ & $(0.053)$ \\
& & {$[0.049]^{* * *}$} & {$[0.049]^{* * *}$} & {$[0.053]^{* * *}$} & {$[0.053]^{* * *}$} & {$[0.051]^{* * *}$} \\
D $\left(K_{O I}=0\right)$ & & $(0.008)$ & $(0.007)$ & $(0.007)$ & $(0.007)$ & $(0.007)$ \\
& & -0.079 & -0.079 & -0.054 & -0.076 & 0.039 \\
$E / K_{P}$ & & $(0.051)$ & $(0.047)$ & $(0.047)$ & $(0.049)$ & $(0.050)$ \\
& & & $0.704^{* * *}$ & $0.633^{* * *}$ & $0.686^{* * *}$ & $0.500^{* * *}$ \\
ln $K_{P}$ & & & $(0.076)$ & $(0.071)$ & $(0.074)$ & $(0.100)$ \\
& 0.006 & 0.007 & 0.007 & 0.010 & 0.009 & 0.011 \\
Industry dummies & No & No & No & Yes & No & No \\
Year fixed effects & Yes & Yes & Yes & Yes & Yes & Yes \\
$R^{2}$ & 0.177 & 0.238 & 0.339 & 0.396 & 0.301 & 0.318 \\
Standard Error & 0.616 & 0.593 & 0.552 & 0.530 & 0.565 & 0.559 \\
Panel Durbin-Watson & 0.265 & 0.282 & 0.364 & 0.385 & 0.413 & 0.335 \\
Observations & 3494 & 3494 & 3494 & 3494 & 3114 & 3114 \\
Firms & 380 & 380 & 380 & 380 & 380 & 380 \\
& & & & & & \\
\hline
\end{tabular}

Note: Robust standard errors clustered on firm in parentheses

Elasticity at the means in square brackets, with its standard error below it

In column (5), all right hand side variables are lagged one year

In column (6), the instruments are the right hand side variables lagged one year

*** , and ${ }^{*}$ denote significance at the $1 \%, 5 \%$ and $10 \%$ levels, respectively, for a two-tail test 
Table 4

Regressions with Firm Effects

Dependent Variable: $\ln \left(V / K_{P}\right)$

\begin{tabular}{|c|c|c|c|c|c|}
\hline & $(1)$ & $(2)$ & (3) & $(4)$ & $(5)$ \\
\hline Regressor & $\begin{array}{l}\text { OLS with } \\
\text { industry } \\
\text { fixed effects }\end{array}$ & $\begin{array}{l}\text { OLS with } \\
\text { random } \\
\text { firm effects }\end{array}$ & $\begin{array}{l}\text { OLS with firm } \\
\text { fixed effects }\end{array}$ & $\begin{array}{l}\text { OLS with firm } \\
\text { fixed effects }\end{array}$ & $\begin{array}{l}\text { GMM-SYS with } \\
\text { lag } 2+ \\
\text { instruments }\end{array}$ \\
\hline Lagged dependent variable & & & & $\begin{array}{l}0.484^{* * *} \\
(0.023)\end{array}$ & $\begin{array}{l}0.706^{* * *} \\
(0.036)\end{array}$ \\
\hline$K_{K} / K_{P}$ & $\begin{array}{l}0.785^{* * *} \\
(0.117)\end{array}$ & $\begin{array}{l}0.688^{* * *} \\
(0.117)\end{array}$ & $\begin{array}{l}0.428^{* * *} \\
(0.140)\end{array}$ & $\begin{array}{l}0.315^{* * *} \\
(0.087)\end{array}$ & $\begin{array}{l}0.302^{* * * *} \\
(0.071)\end{array}$ \\
\hline$K_{O I} / K_{P}$ & $\begin{array}{l}0.413^{* * *} \\
(0.054)\end{array}$ & $\begin{array}{l}0.353^{* * *} \\
(0.048)\end{array}$ & $\begin{array}{l}0.250^{* * * *} \\
(0.064)\end{array}$ & $\begin{array}{l}0.192^{* * *} \\
(0.054)\end{array}$ & $\begin{array}{l}0.146^{* * *} \\
(0.028)\end{array}$ \\
\hline$E / K_{P}$ & $\begin{array}{l}0.631^{* * *} \\
(0.071)\end{array}$ & $\begin{array}{l}0.428^{* * *} \\
(0.053)\end{array}$ & $\begin{array}{l}0.352^{* * *} \\
(0.051)\end{array}$ & $\begin{array}{l}0.239^{* * * *} \\
(0.045)\end{array}$ & $\begin{array}{l}0.251^{* * *} \\
(0.056)\end{array}$ \\
\hline $\ln K_{P}$ & $\begin{array}{l}0.011 \\
(0.015)\end{array}$ & $\begin{array}{l}-0.047^{* * *} \\
(0.018)\end{array}$ & $\begin{array}{l}-0.158^{* * *} \\
(0.042)\end{array}$ & $\begin{array}{l}-0.182^{* * *} \\
(0.032)\end{array}$ & $\begin{array}{l}-0.005 \\
(0.014)\end{array}$ \\
\hline Long run coefficient: $K_{K} / K_{P}$ & & & & $\begin{array}{l}0.609^{* * *} \\
(0.172)\end{array}$ & $\begin{array}{l}1.026^{* * *} \\
(0.221)\end{array}$ \\
\hline Long run coefficient: $K_{O I} / K_{P}$ & & & & $\begin{array}{l}0.372^{* * *} \\
(0.107)\end{array}$ & $\begin{array}{l}0.495^{* * *} \\
(0.091)\end{array}$ \\
\hline Year fixed effects & Yes & Yes & Yes & Yes & Yes \\
\hline Observations & 3494 & 3494 & 3494 & 3114 & 3096 \\
\hline Firms & 380 & 380 & 380 & 380 & 379 \\
\hline$R^{2}$ & 0.395 & 0.372 & 0.381 & 0.522 & \\
\hline Standard Error Within & 0.530 & 0.347 & 0.321 & 0.271 & \\
\hline Share variance across firms & 0.566 & 0.602 & 0.737 & 0.662 & \\
\hline T-stat for AR(1) test & $69.9^{* * *}$ & $29.0^{* * *}$ & $30.1^{* * *}$ & $1.8^{* * *}$ & \\
\hline Hansen test (df) & & & & & $255.1(206)^{* *}$ \\
\hline AR(1) test (p-value) & & & & & $-10.7(0.000)^{* * *}$ \\
\hline AR(2) test (p-value) & & & & & $2.0(0.050)^{* *}$ \\
\hline
\end{tabular}

Note: Robust standard errors clustered on firm in parentheses.

Hausman test for correlated effects: $\chi_{8}^{2}=137.0(p$-value $=0.000)$.

The instruments in column (5) are lags 2 and earlier (level and differenced) of the dependent and independent variables.

,**** and ${ }^{*}$ denote significance at the 1\%, 5\% and 10\% levels, respectively, for a two-tail test. 
Table 5

Nonlinear Regressions by Pavitt Sector

Dependent Variable: $\ln \left(V / K_{P}\right)$

\begin{tabular}{lllll}
\hline & $(1)$ & $(2)$ & $(3)$ & $(4)$ \\
\hline Regressor & & \multicolumn{2}{c}{ Pavitt Sector } & Science-based \\
\hline & Supplier-dominated & Scale-intensive & Specialized-supplier & $1.73^{* * *}$ \\
$K_{K} / K_{P}$ & & & & $(0.50)$ \\
& 4.24 & $1.80^{* * *}$ & $1.28^{* * *}$ & {$[0.155]^{* * *}$} \\
& $(3.45)$ & $(0.65)$ & $(0.38)$ & $(0.034)$ \\
$K_{O I} / K_{P}$ & {$[0.102]$} & {$[0.093]^{* * *}$} & {$[0.152]^{* * *}$} & $1.51^{* *}$ \\
& $(0.063)$ & $(0.025)$ & $(0.034)$ & $(0.64)$ \\
& $2.74^{* * *}$ & $0.73^{* * *}$ & 0.83 & {$[0.055]^{* *}$} \\
$E / K_{P}$ & $(0.89)$ & $(0.18)$ & $(0.56)$ & $(0.016)$ \\
ln $K_{P}$ & {$[0.097]^{* * *}$} & {$[0.077]^{* * *}$} & {$[0.030]$} & $0.48^{* * *}$ \\
& $(0.022)$ & $(0.013)$ & $(0.019)$ & $(0.18)$ \\
Year fixed effects & 0.41 & $0.50^{* * *}$ & $0.48^{* * *}$ & 0.03 \\
$R^{2}$ & $(0.46)$ & $(0.18)$ & $(0.13)$ & $(0.02)$ \\
Standard Error & 0.08 & 0.03 & $-0.10^{* * *}$ & $(0.04)$ \\
Panel Durbin-Watson & $(0.06)$ & $(0.02)$ & & Yes \\
Observations & 0.350 & & Yes & 0.289 \\
Firms & 316 & 0.352 & 0.357 & 0.581 \\
& 32 & 0.549 & 0.541 & 0.294 \\
\hline
\end{tabular}

Note: NLLS regressions. Robust standard errors clustered on firm in parentheses Elasticity at the means in square brackets, with its standard error below it ${ }_{* * * * *}^{* *}$ and ${ }^{*}$ denote significance at the $1 \%, 5 \%$ and $10 \%$ levels, respectively, for a two-tail test 
Table 6

Market Value Regressions Allowing for Uncertainty Dependent Variable: $\ln \left(V / K_{P}\right)$

\begin{tabular}{lllll}
\hline Regressor & $(1)$ & $(2)$ & $(3)$ & $(4)$ \\
\hline & & & & \\
$K_{K} / K_{P}$ & $1.90^{* * *}$ & $2.23^{* * *}$ & $1.95^{* * *}$ & $2.64^{* * *}$ \\
$K_{O I} / K_{P}$ & $(0.34)$ & $(0.45)$ & $(0.49)$ & $(0.86)$ \\
$\hat{h}^{\dagger}$ & $0.81^{* * *}$ & $0.97^{* * *}$ & $0.85^{* * * *}$ & $1.01^{* * *}$ \\
$\hat{h}^{2}$ & $(0.18)$ & $(0.23)$ & $(0.22)$ & $(0.25)$ \\
& & $10.28^{*}$ & -0.89 & $\left(7.50^{*}\right.$ \\
$\hat{h} \times\left(K_{K} / K_{P}\right)$ & $(5.66)$ & $(11.82)$ & \\
$E / K_{P}$ & & & 192.8 & -15.93 \\
& & & $(215.9)$ & $(29.73)$ \\
$\ln K_{P}$ & & & & $0.69^{* * *}$ \\
& $0.54^{* * *}$ & $0.67^{* * *}$ & $0.59^{* * *}$ & $0.16)$ \\
Year fixed effects & $(0.11)$ & $(0.15)$ & $(0.15)$ & $(0.014)$ \\
$R^{2}$ & 0.013 & 0.018 & 0.017 & \\
Standard Error & $(0.014)$ & $(0.014)$ & $(0.014)$ & Yes \\
Panel Durbin-Watson & & & & 0.350 \\
Observations & 0.325 & Yes & Yes & 0.559 \\
Firms & 0.3114 & 0.315 & 0.316 & 0.328 \\
& 380 & 0.559 & 0.559 & 3114 \\
\hline
\end{tabular}

Note: NLLS regressions. Robust standard errors clustered on firm in parentheses

† Industry sales variance estimated as shown in Appendix A, Table A3.

***** and ${ }^{*}$ denote significance at the $1 \%, 5 \%$ and $10 \%$ levels, respectively, for a two-tail test 
Appendix A: Industry Coverage

Table A1

Observations by Industry and Pavitt sector

\begin{tabular}{|c|c|c|c|c|c|}
\hline Pavitt sector & Industry & Observations & Firms & $\begin{array}{r}\text { Mean R\&D } \\
\text { growth }\end{array}$ & $\begin{array}{r}\text { Mean ADV } \\
\text { growth }\end{array}$ \\
\hline (i) supplier-dominated & Gems and jewellery & 7 & 1 & $0.23 \%$ & $4.81 \%$ \\
\hline (i) supplier-dominated & Leather products & 30 & 3 & $3.21 \%$ & $0.60 \%$ \\
\hline (i) supplier-dominated & Rubber products & 20 & 2 & $0.91 \%$ & $-0.88 \%$ \\
\hline (i) supplier-dominated & Textiles and textile products & 259 & 26 & $1.42 \%$ & $-1.08 \%$ \\
\hline (ii) scale-intensive & Domestic appliances & 60 & 7 & $1.29 \%$ & $4.11 \%$ \\
\hline (ii) scale-intensive & Automobiles & 101 & 12 & $1.59 \%$ & $0.96 \%$ \\
\hline (ii) scale-intensive & Cement & 140 & 14 & $1.33 \%$ & $0.78 \%$ \\
\hline (ii) scale-intensive & Food and agricultural products & 352 & 39 & $0.89 \%$ & $0.51 \%$ \\
\hline (ii) scale-intensive & Glass and glassware & 25 & 3 & $-1.97 \%$ & $7.93 \%$ \\
\hline (ii) scale-intensive & Metals and metal products & 217 & 22 & $0.51 \%$ & $1.03 \%$ \\
\hline (ii) scale-intensive & Other consumer goods & 30 & 3 & $-2.80 \%$ & $-0.17 \%$ \\
\hline (ii) scale-intensive & Other construction products & 171 & 18 & $0.62 \%$ & $2.71 \%$ \\
\hline (ii) scale-intensive & Paper and paper products & 129 & 13 & $1.79 \%$ & $0.08 \%$ \\
\hline (ii) scale-intensive & Personal care & 10 & 3 & $-2.92 \%$ & $1.46 \%$ \\
\hline (iii) specialized supplier & Automobile ancillaries & 419 & 43 & $1.58 \%$ & $1.18 \%$ \\
\hline (iii) specialized supplier & Non-electrical machinery & 271 & 35 & $2.59 \%$ & $1.94 \%$ \\
\hline (iv) science-based & Chemicals & 600 & 62 & $0.79 \%$ & $0.08 \%$ \\
\hline (iv) science-based & Electrical machinery & 129 & 15 & $2.36 \%$ & $2.32 \%$ \\
\hline (iv) science-based & Electronics & 68 & 8 & $1.39 \%$ & $0.83 \%$ \\
\hline (iv) science-based & Petroleum products & 64 & 7 & $-0.36 \%$ & $2.58 \%$ \\
\hline (iv) science-based & Drugs and pharmaceuticals & 268 & 31 & $2.72 \%$ & $1.76 \%$ \\
\hline (iv) science-based & Plastic products & 124 & 13 & $1.21 \%$ & $0.09 \%$ \\
\hline Total & & 3494 & 380 & $1.32 \%$ & $1.00 \%$ \\
\hline
\end{tabular}


Appendix B: Robustness Checks and GARCH Estimation

\section{B.1 GMM Estimates}

Table B1

GMM-SYS regressions

Dependent Variable: $\ln \left(V / K_{P}\right)$

\begin{tabular}{|c|c|c|c|c|c|c|}
\hline & $(1)$ & $(2)$ & (3) & $(4)$ & (5) & $(6)$ \\
\hline & \multicolumn{6}{|c|}{ Estimation Method } \\
\hline Regressor & $\begin{array}{l}\text { GMM-SYS } \\
\text { with lag } 2+ \\
\text { instruments }\end{array}$ & $\begin{array}{l}\text { GMM-SYS } \\
\text { with lag } 3+ \\
\text { instruments }\end{array}$ & $\begin{array}{l}\text { GMM-SYS } \\
\text { with lag 3/4 } \\
\text { instruments }\end{array}$ & $\begin{array}{l}\text { GMM-SYS } \\
\text { with lag 2+ } \\
\text { instruments }\end{array}$ & $\begin{array}{l}\text { GMM-SYS } \\
\text { with lag 3+ } \\
\text { instruments }\end{array}$ & $\begin{array}{l}\text { GMM-SYS } \\
\text { with lag 3/4 } \\
\text { instruments }\end{array}$ \\
\hline Lagged regressand & & & & $\begin{array}{l}0.706^{* * *} \\
(0.036)\end{array}$ & $\begin{array}{l}0.694^{* * *} \\
(0.039)\end{array}$ & $\begin{array}{l}0.677^{* * *} \\
(0.045)\end{array}$ \\
\hline$K_{K} / K_{P}$ & $\begin{array}{l}0.991^{* * *} \\
(0.174)\end{array}$ & $\begin{array}{l}0.711^{* * *} \\
(0.130)\end{array}$ & $\begin{array}{l}0.668^{* * *} \\
(0.144)\end{array}$ & $\begin{array}{l}0.302^{* * *} \\
(0.071)\end{array}$ & $\begin{array}{l}0.326^{* * * *} \\
(0.094)\end{array}$ & $\begin{array}{l}0.238^{* * * *} \\
(0.110)\end{array}$ \\
\hline$K_{O I} / K_{P}$ & $\begin{array}{l}0.336^{* * *} \\
(0.055)\end{array}$ & $\begin{array}{l}0.287^{* * * *} \\
(0.073)\end{array}$ & $\begin{array}{l}0.287^{* * *} \\
(0.079)\end{array}$ & $\begin{array}{l}0.146^{* * *} \\
(0.028)\end{array}$ & $\begin{array}{l}0.169^{* * * *} \\
(0.039)\end{array}$ & $\begin{array}{l}0.165^{* * * *} \\
(0.039)\end{array}$ \\
\hline$E / K_{P}$ & $\begin{array}{l}0.793^{* * *} \\
(0.115)\end{array}$ & $\begin{array}{l}0.802^{* * *} \\
(0.149)\end{array}$ & $\begin{array}{l}0.821^{* * * *} \\
(0.153)\end{array}$ & $\begin{array}{l}0.251^{* * *} \\
(0.056)\end{array}$ & $\begin{array}{l}0.181^{* * *} \\
(0.073)\end{array}$ & $\begin{array}{l}0.203^{* * *} \\
(0.085)\end{array}$ \\
\hline $\ln K_{P}$ & $\begin{array}{l}0.002 \\
(0.035)\end{array}$ & $\begin{array}{l}-0.024 \\
(0.035)\end{array}$ & $\begin{array}{l}0.018 \\
(0.035)\end{array}$ & $\begin{array}{l}-0.005 \\
(0.014)\end{array}$ & $\begin{array}{l}-0.011 \\
(0.016)\end{array}$ & $\begin{array}{l}0.001 \\
(0.019)\end{array}$ \\
\hline $\begin{array}{l}\text { Long run } \\
\text { coefficient: } K_{K} / K_{P}\end{array}$ & & & & $\begin{array}{l}1.026^{* * *} \\
(0.221)\end{array}$ & $\begin{array}{l}1.067^{* * *} \\
(0.286)\end{array}$ & $\begin{array}{l}0.735^{* * *} \\
(0.312)\end{array}$ \\
\hline $\begin{array}{l}\text { Long run } \\
\text { coefficient: } K_{O I} / K_{P}\end{array}$ & & & & $\begin{array}{l}0.495^{* * *} \\
(0.091)\end{array}$ & $\begin{array}{l}0.553^{* * *} \\
(0.133)\end{array}$ & $\begin{array}{l}0.510^{* * *} \\
(0.125)\end{array}$ \\
\hline Observations & 3494 & 3494 & 3494 & 3096 & 3096 & 3096 \\
\hline Firms & 380 & 380 & 380 & 379 & 379 & 379 \\
\hline Hansen test (df) & $279.3(216)^{* * *}$ & $224.1(184)^{* * *}$ & $165.1(96)^{* * *}$ & $255.1(206)^{* * *}$ & $220.2(170)^{* * *}$ & $155.1(95)^{* * *}$ \\
\hline AR(1) test (p-value) & $-6.7(0.000)^{* * *}$ & $-6.9(0.000)^{* * *}$ & $-6.8(0.000)^{* * *}$ & $-10.7(0.000)^{* * *}$ & $-10.4(0.000)^{* * *}$ & $-9.9(0.000)^{* * *}$ \\
\hline AR(2) test (p-value) & $-1.0(0.328)$ & $-0.9(0.357)$ & $-0.9(0.365)$ & $2.0(0.050)^{* *}$ & $1.9(0.065)^{*}$ & $1.9(0.065)^{*}$ \\
\hline
\end{tabular}

Note: Robust standard errors in parentheses

The instruments are lags (level and differenced) of the dependent and independent variables - in columns (1) and (4) they include lag 2 and earlier values, in columns (2) and (5) lag 3 and earlier values, and in columns (3) and (6) lags 3 and 4 only. ***** and ${ }^{*}$ denote significance at the $1 \%, 5 \%$ and $10 \%$ levels, respectively, for a two-tail test 


\section{B.2 GARCH Model for Sales}

Table B2 presents the estimation results based on the GARCH model 8a-8c, outlined in the main text. Our preferred estimates here are those in column (5), which allow for industry and size differences in the mean variance, but not in the lagged variances, for reasons discussed in the main text above.

Table B2

GARCH Model for log(Sales)

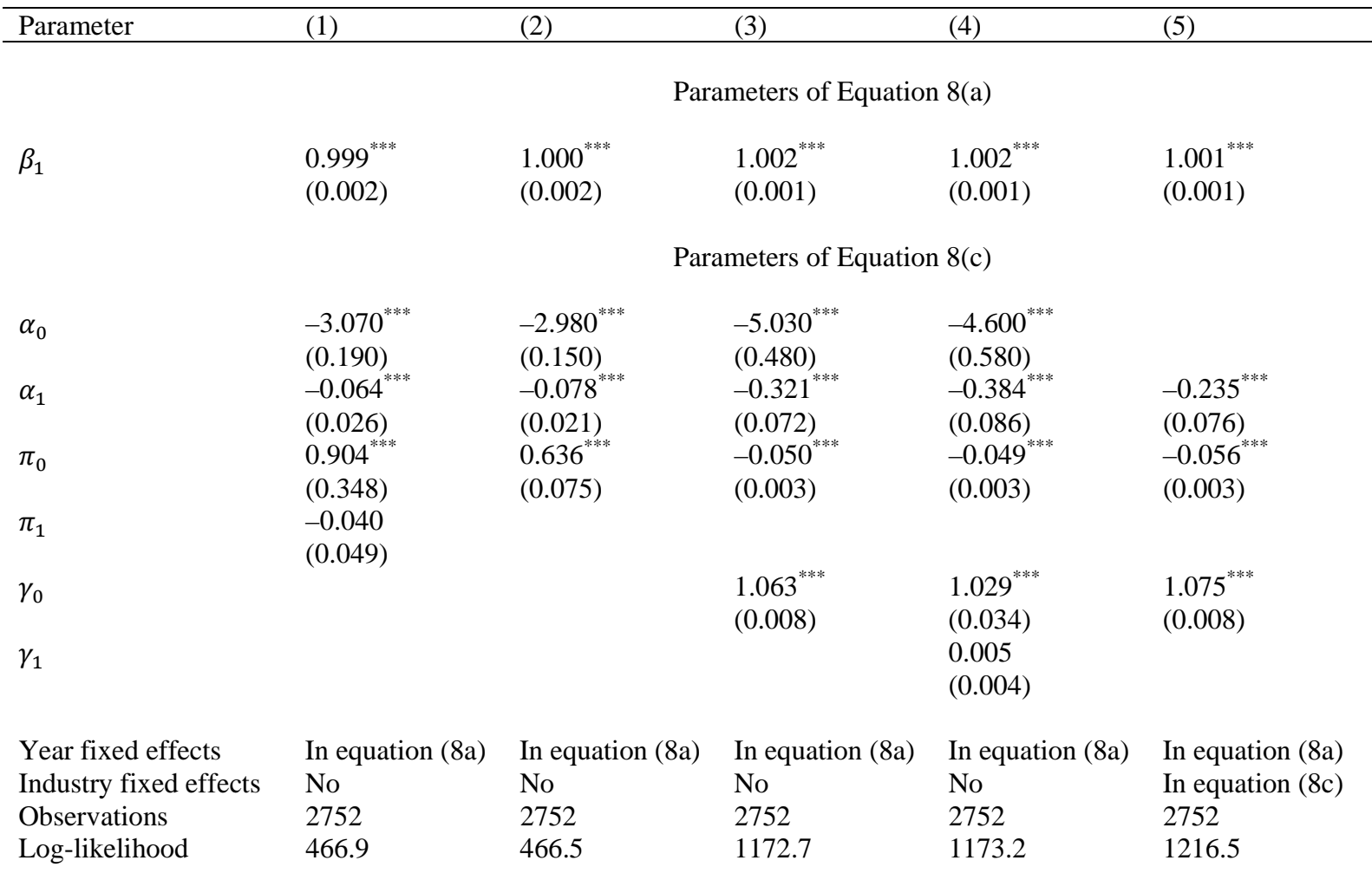

Equations (8a)-(8c) in the text are reproduced below for convenience:

$y_{i t}=\mu_{t}+\beta_{1} y_{i, t-1}+\varepsilon_{i t}$

$\varepsilon_{i t} \sim \Phi\left(0, h_{i t}\right)$

$h_{i t}=\exp \left(\mu_{j}+\alpha_{1} x_{i t}\right)+\left(\pi_{0}+\pi_{1} x_{i t}\right)\left(\hat{\varepsilon}_{i, t-1}\right)^{2}+\left(\gamma_{0}+\gamma_{1} x_{i t}\right) h_{i, t-1}$

where $y$ is $\log$ (sales), $x$ is $\log \left(K_{P}\right), j$ is the industry to which the $i^{\text {th }}$ firm belongs, $\mu_{t}$ are the year dummies, and $\mu_{j}$ are the industry dummies. 


\section{B.3 Varying the Depreciation Rate of Knowledge Capital}

As a further robustness check, we compute an alternative measure of the stock of knowledge capital, allowing for a $30 \%$ per annum rate of depreciation instead of the earlier $15 \%$ per annum. This transformed regressor is denoted $K_{K}^{\prime} / K_{P}$. The results are reported in Table B3, which duplicates Table 3 (the linear model). The results are exactly as expected - the only coefficient that changes appreciably is that for R\&D, which nearly doubles. Note that if R\&D grows at a constant rate $g$ and depreciates at a constant rate $\theta, \mathrm{R} \& \mathrm{D}$ capital is simply $K_{K t}=R D_{t} /(g+\theta)$, which implies that $K_{K} / K_{K}^{\prime}=(g+0.30) /(g+0.15)$, so that the corresponding coefficients will be approximately in the inverse ratio of $2=0.30 / 0.15$ if $g$ is small. Our conclusion is that a depreciation rate of 15 per cent is more appropriate, as it corresponds to the expected value of the coefficient, which is unity, and is more useful for comparison to prior work by others.

Table B3

Linear Regressions

Dependent Variable: $\ln \left(V / K_{P}\right)$

\begin{tabular}{lllllll}
\hline & $(1)$ & $(2)$ & $(3)$ & $(4)$ & $(5)$ & $(6)$ \\
\hline Regressor & OLS & OLS & OLS & OLS & OLS, lag RHS & IV \\
\hline & & & & & & \\
$K_{K}^{\prime} / K_{P} \dagger$ & $1.847^{* * *}$ & $1.733^{* * *}$ & $1.703^{* * *}$ & $1.418^{* * * *}$ & $1.607^{* * *}$ & $1.785^{* * *}$ \\
& $(0.203)$ & $(0.191)$ & $(0.163)$ & $(0.177)$ & $(0.175)$ & $(0.182)$ \\
$K_{O I} / K_{P}$ & & $0.379^{* * *}$ & $0.380^{* * *}$ & $0.398^{* * *}$ & $0.402^{* * *}$ & $0.395^{* * *}$ \\
& & $(0.061)$ & $(0.050)$ & $(0.056)$ & $(0.055)$ & $(0.052)$ \\
$\mathrm{D}\left(K_{O I}=0\right)$ & & -0.077 & -0.077 & -0.053 & -0.074 & 0.039 \\
& & $(0.050)$ & $(0.047)$ & $(0.048)$ & $(0.049)$ & $(0.052)$ \\
$E / K_{P}$ & & & $0.691^{* * *}$ & $0.624^{* * *}$ & $0.673^{* * *}$ & $0.500^{* * *}$ \\
& & & $(0.076)$ & $(0.072)$ & $(0.075)$ & $(0.100)$ \\
$\ln K_{P}$ & & & 0.005 & 0.008 & 0.007 & 0.009 \\
& 0.004 & 0.005 & $(0.013)$ & $(0.015)$ & $(0.014)$ & $(0.014)$ \\
Industry dummies & No & No & No & Yes & No & No \\
Year fixed effects & Yes & Yes & Yes & Yes & Yes & Yes \\
$R^{2}$ & 0.184 & 0.249 & 0.346 & 0.399 & 0.304 & 0.325 \\
Standard Error & 0.614 & 0.589 & 0.550 & 0.529 & 0.564 & 0.556 \\
Panel Durbin-Watson & 0.269 & 0.288 & 0.366 & 0.385 & 0.415 & 0.340 \\
Observations & 3494 & 3494 & 3494 & 3494 & 3114 & 3114 \\
Firms & 380 & 380 & 380 & 380 & 380 & 380 \\
& & & & & & \\
\hline
\end{tabular}

Note: $\dagger K_{K}^{\prime}=$ Knowledge capital at $30 \%$ depreciation

Robust standard errors clustered on firm in parentheses

Elasticity at the means in square brackets, with its standard error below it

In column (5), all right hand side variables are lagged one year

In column (6), the instruments are the right hand side variables lagged one year

${ }_{* * * * * *}^{* *}$ and ${ }^{*}$ denote significance at the $1 \%, 5 \%$ and $10 \%$ levels, respectively, for a two-tail test 